Portland State University

PDXScholar

1987

\title{
Molecular cloning of spinach chloroplast DNA isolated by alkaline lysis
}

Robert Gray Drager

Portland State University

Follow this and additional works at: https://pdxscholar.library.pdx.edu/open_access_etds

Part of the Genetics and Genomics Commons, and the Plant Sciences Commons Let us know how access to this document benefits you.

Recommended Citation

Drager, Robert Gray, "Molecular cloning of spinach chloroplast DNA isolated by alkaline lysis" (1987). Dissertations and Theses. Paper 3747.

https://doi.org/10.15760/etd.5631

This Thesis is brought to you for free and open access. It has been accepted for inclusion in Dissertations and Theses by an authorized administrator of PDXScholar. Please contact us if we can make this document more accessible: pdxscholar@pdx.edu. 
AN ABSTRACT OF THE THESIS OF Robert Gray Drager for the Master of Science in Biology presented February 27.1987.

Title: Molechlar Cloning of Spinach Chloroplast DNA Isolated by Alkaline Lysis.

APPROVED BY MEMBERS OF THE THESIS COMMITTEE:

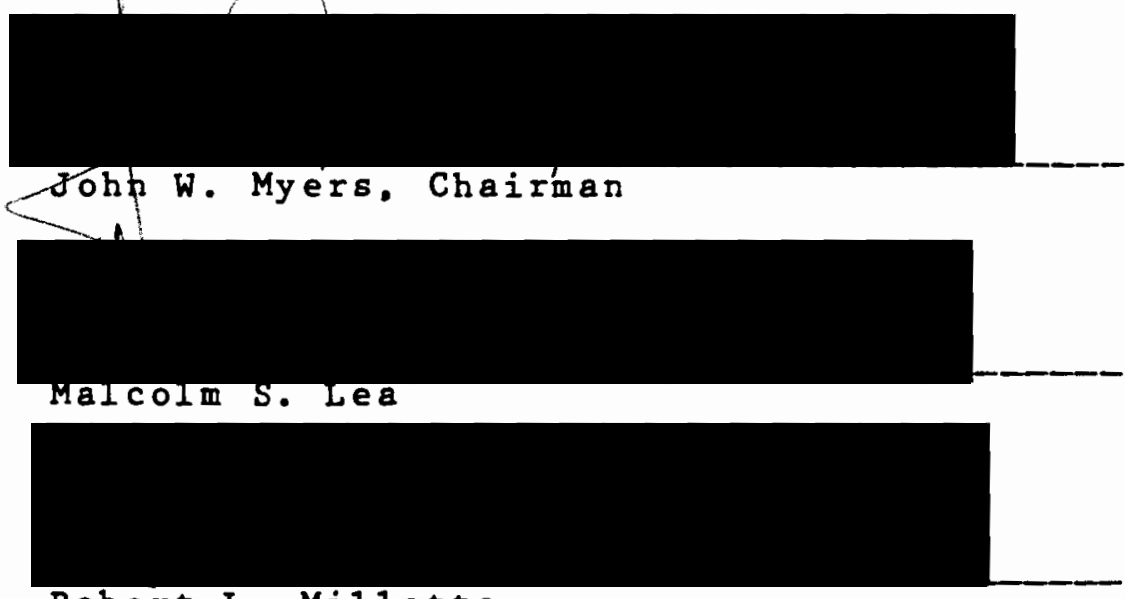

\section{Robert L. Millette}

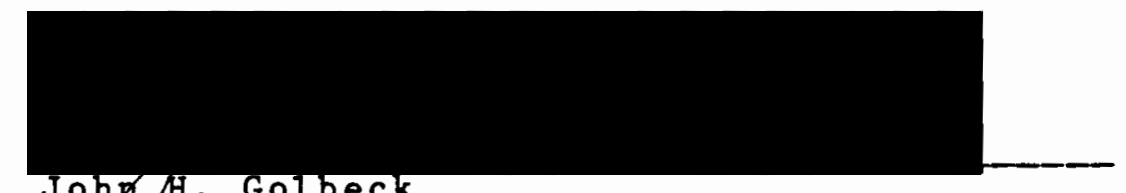

Chloroplast genomes of land plants show conservation of structure and gene arrangement. The spinach chloroplast genome is comprised of a covalently closed, circular DNA molecule of $150 \mathrm{kilobases}$ and is typical of these plants. Approximately $20 \%$ of the proteins found in the spinach chloroplast are encoded by the chloroplast genome and translated on chloroplast ribosomes. The remainder are 
encoded on chromosomes in the nucleus, translated on cytoplasmic ribosomes and transported into the chloroplast. Spinach chloroplast DNA was isolated from crude chloroplast preparations by a new method. Chloroplasts were lysed with alkaline sodium dodecyl sulfate, contaminating macromolecules precipitated with acidified potassium acetate and plastid DNA was purified by phenol:chloroform extraction and ethanol:ammonium acetate precipitation. The yield was approximately 50 ug chloroplast DNA per 100 grams leaf material. The DNA consisted of $10 \%$ circular molecules and $90 \%$ inear molecules.

The chloroplast DNA was digested with restriction enzyme Pst and the fragments were cloned into the plasmid vector puC9. Several recombinant plasmids were isolated and the chloroplast DNA inserts identified. The recombinant plasmid pRD105 containing the Pst \#5 fragment was subjected to further investigation. The ClaI restriction sites of the Pst \#5 fragment were mapped and the insert was subcloned into the plasmid vector pGEM4, which bears bacteriophage sP6 and T7 RNA polymerase promoter sequences. 


\title{
MOLECULAR CLONING OF SPINACH CHLOROPLAST DNA ISOLATED BY ALKALINE LYSIS
}

\author{
by \\ ROBERT GRAY DRAGER
}

A thesis submitted in partial fulfillment of the requirements for the degree of

\author{
MASTER OF SCIENCE \\ in \\ B I OL OGY
}

Portland State University

1987 
TO THE OFEICE OF GRADUATE STUDIES AND RESEARCH:

The members of the Committee approve the thesis of Robert Gray Drager presented Eebruary 27, 1987 .

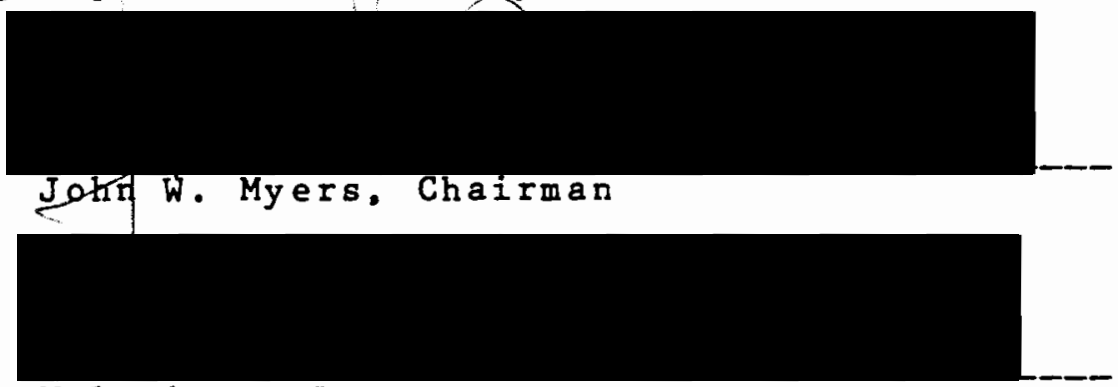

Malcolm S. Lea

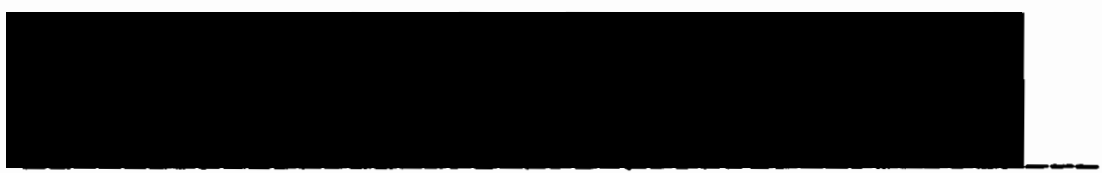

Robert L. Millette

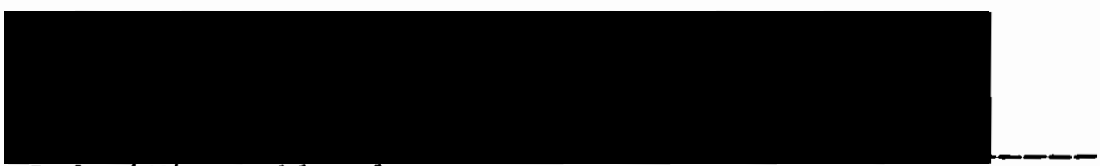

John/H/. Golbeck

APPROVED :

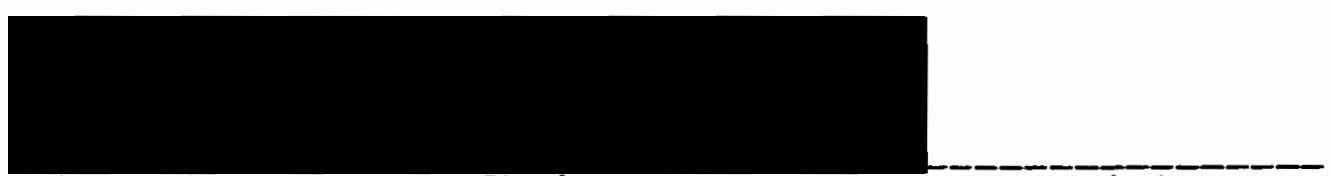

Richard Petersen, Chairman, Department of Biology

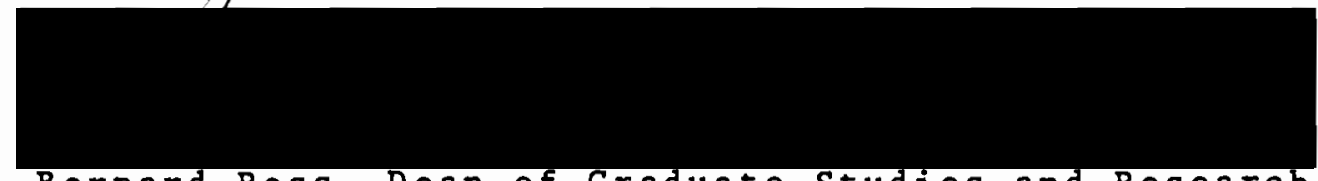

Bernard Ross, Dean of Graduate Studies and Research 


\section{ACKNOWL EDGMENTS}

Thys thesis is dedicated to the memory of my mother. Peg Drager. Special thanks to Jack Myers, my friend and mentor, for his patience and wisdom. Acknowledgments to fellow graduate students Terry Coons and Josh Clark for their help and comraderie and scott Lamb for his artistic talent. 
TABLE OF CONTENTS

PAGE

ACKNOWLEDGEMENTS

i i i

LIST OF FIGURES

vi

INTRODUCTION

MATERIALS AND METHODS . . . . . . . . . . . . 23

Bacterial Strains and Plasmids . . . . . . 23

Isolation of Spinach Chloroplast DNA . . . . 25

Restriction Analysis of Spinach Chloroplast

DNA . . . . . . . . . . . . . . 26

Cloning of Spinach Chloroplast DNA into pUC

Plasmids . . . . . . . . . . . . . . . 27

Identification of Cloned Chloroplast DNA

Fragments................... 29

Subcloning the PstI \#5 Fragment into pGEM4 . . 32 RESULTS . . . . . . . . . . . . . . . . 34

Spinach Chloroplast DNA Isolation....... 34

Cloning of Spinach Chloroplast DNA into pUC

Plasmids . . . . . . . . . . . . . . 34

Identification of Cloned Chloroplast DNA

Fragments . . . . . . . . . . . . . 37

Subcloning the PstI \#5 Fragment into pGEM4 . . 38

Mapping of the ClaI Restiction Sites in

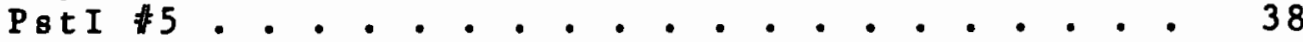


PAGE

Mapping of the C1aI Restiction Sites in

PstI $\# 5$. . . . . . . . . . . . . 38

DISCUSSION •

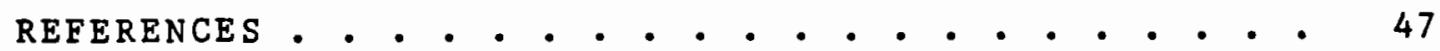




\section{LIST OF FIGURES}

F I GURE

PAGE

1. Structure of Spinach Chloroplast Genome with rRNA Genes . . . . . . . . . . . . . . 5

2. Pst and Sali Restriction Sites of Spinach Chloroplast Genome . . . . . . . . . . 7

3. Map of Spinach Chloroplast Genome Protein

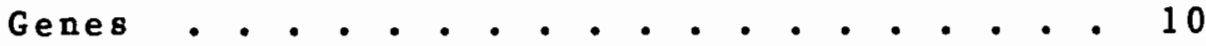

4. Spinach Chloroplast DNA Isolated by Alkaline

Lysis . . . . . . . . . . . . . . 35

5. Agarose Gel Electrophoresis of Spinach

Chloroplast DNA Isolated by Alkaline

Lysis and Purified by Repeated Et OH:

Ammonium Acetate Precipitation. . . . . 36

6. Electrophoretic Analysis of Recombinant

Plasmids pRDllo, pRD108 and pRDl05... . 39

7. Electrophoretic Analysis of ClaI Digestion of pRD105 . . . . . . . . . . . . . . . 40

8. Positions of ClaI Restriction Sites in spinach Chloroplast Genome Pst Fragment $\# 5$..... 


\section{INTRODUCTION}

Chloroplasts of eukaryotic photoautotrophs have been extensively studied as the sites of conversion of sunlight to chemical energy, fixation of $\mathrm{CO}_{2}$ to organic carbon and production of molecular oxygen. Investigation of the biochemical processes of the Calvin cycle and the photosynthetic apparatus continue at a rapid pace, but since chloroplasts were shown to contain their own geneteic material (55) and protein synthesizing machinery (46), few areas of plant biology have been pursued as enthusiastically as chloroplast molecular genetics.

Characterization of the chloroplast genome by electron microscopy, renaturation kinetics and CsCl buoyant density centrifugation $(34,41,42)$ showed the gross structure to be a supercoiled, circular, double-stranded DNA molecule with 37\% G-C content and no highly repetitive sequences. This genome structure is similar to that of prokaryotes and quite different from the linear, histone-containing nuclear chromosomes. Other similarities between chloroplasts and prokaryotes are the size of the ribosomes (70S) and the antibiotic sensitivities of the ribosomes and RNA polymerases. These similarities support the endosymbiotic hypothesis of chloroplast and mitochondria evolution 
supported by Margulis (48). namely that these subcellular organelles were once free-living organisms similar to modern prokaryotes, and became incorporated into cells with the characteristics of modern eukaryotes.

These organelies are not capable of autonomous survival since approximately $80 \%$ of the organelle proteins are encoded by nuclear genes. synthesized on cytoplasmic ribosomes and transported into the organelle (38). In the endosymbiotic hypothesis this situation is presumed to have arisen by the net transfer of genetic material from the organelle to the nucleus. Evidence for transfer of genetic material between cellular compartments is provided by the existence ot homologous DNA seqences in chloroplasts. mitochondria and nuclei of higher plants $(19,20,61,62)$. The net transfer of DNA has probably been from the chloroplast to the nucleus as suggested by the small size of the chloroplast genome (100-300 kilobases) compared to that of modern prokaryotes (approximately 4000 kilobases). The size of the plant mitochondria genome is much more variable, 100-1000 kilobases $(\mathrm{kb})$. Another hypothesis. supported by Bogorad (7), is that the organelles arose as buds from the nuclei ot ancestral cells and the net transfer of genetic material has been from the nucleus to the organelle. The fact that there is a high degree of homology between chloroplast genes and proteins and those of Escherrichia coli is powerful evidence for the endosymbiotic hypothesis. 
Whatever the evolutionary history of chloroplasts, the further characterization of the structure and regulation of the chloroplast genome is an important and promising goal. Much of the promise is imparted by the small size of the chloroplast genome which facilitates mapping and sequencing. Chloroplast DNA can be isolated and clone banks of some species have been established (50). This allows for the detailed investigation, by sequencing and other methods, of the way genes of the chloroplast are coordinated with and controlled by the nucleus in response to environmental stimuli. The importance of understanding the biochemical processes that occur in chloroplasts cannot be overemphsized and there is potential for genetic modification of these processes (10). Examples of such modifications include increasing the efficiency of $\mathrm{CO}_{2}$ fixation by decreasing the affinity of ribulose 1,5-bisphoshate carboxylase for $\mathrm{O}_{2}$. modifying proteins that are the binding sites of herbicides and introducing prokaryotic genes to perform such functions as N fixation. At this time, the level of knowledge of chloroplast molecular genetics is considerable, many ribosomal RNA, transfer RNA and protein genes have been mapped and sequenced, but the mechanisms of control remain completely undefined. Significant understanding of these control processes is necessary to implement genetic manipulation strategies that could produce benefits in terms of crop improvements, disease resistance and pest control. 
The most striking feature the of chloroplast DNA of higher plants is its uniformity. Almost all chloroplasts so far examined contain circular DNA molecules from $100-300 \mathrm{~kb}$ in size. In any species each chloroplast has a homogeneous population of identical DNA circles characteristic of that species (reviewed in $4,18,24,37,53,71$ ). Land plants show a high degree of conservation in both genome size and gene arrangement. The same chloroplast genome structure has

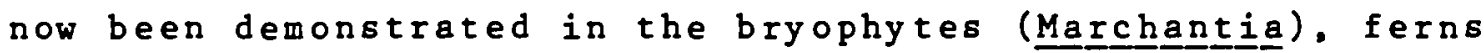
(Osmunda) and gymnosperms (Ginkgo), (52), as well as the angiosperms. The size range is $120-220 \mathrm{~kb}$ and nearly all show the characteristic inverted repeat containing the ribosomal RNA genes. These repeat regions separate the genome into large and small single copy regions (Fig. 1 ). The only exceptions are some legumes which have lost one of the repeat units and show a reduced genome size ( $120 \mathrm{~kb})$. $(51,60)$.

Only in the green algae is there significant variability in chloroplast genome size (reviewed in 53).

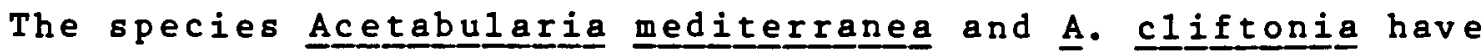
been shown to have complexity of $2000 \mathrm{~kb}$ by renaturation kinetics and form linear molecules up to $600 \mathrm{~kb}$. Other algal groups seem to conform to the usual size and arrangement parameters with the possible exception of some species ot brown algae which have been reported to contain heterogeneous circular DNA populations (53). 


$$
\Omega
$$


In the angiosperms, the chloroplast genome has been best characterized in the genera Zea $(29,61)$, Nicoㅡ므ㅁㅡㅡㅡ (21, 22, 57), Brassica (44), Pisum (12, 41, 42), Spirodela (30, 31), Vicia $(27,28,58)$ and Spingacia $(16,17,35)$. Spinach has been arbitrarily designated as the archetype. The arrangements of the other well characterized genera can be related to spinach by inversions, additions and detetions.

In 14-day spinach leaves, plastid DNA comprises approximately $22 \%$ of the total cellular DNA. There are approximately 100 chloroplasts per cell and 88 plastid genomes per chloroplast. In 24-day leaves, the plastid DNA is $18 \%$ of the total, there are 500 chloroplasts per cell and 24 plastid genomes per chloroplast (56). Electron microscopy suggests that chloroplast DNA replicates in a two step process (43). The first step is the formation of Cairns replivative forked structure and the second step is rolling circle replication. It was proposed that the Cairns mechanism is used for normal DNA duplication and the rolling circle mechanism dominates when rapid DNA synthesis is necessary (43).

The $150 \mathrm{~kb}$ spinach chloroplast genome is divided into four distinct regions. Two $24 \mathrm{~kb}$ inverted repeats separate the $82 \mathrm{~kb}$ (1arge) and $20 \mathrm{~kb}$ (small) single copy regions (Fig. 1). The restriction enzymes SalI and PstI cleave the circular molecule into 11 and 10 fragments, respectively 


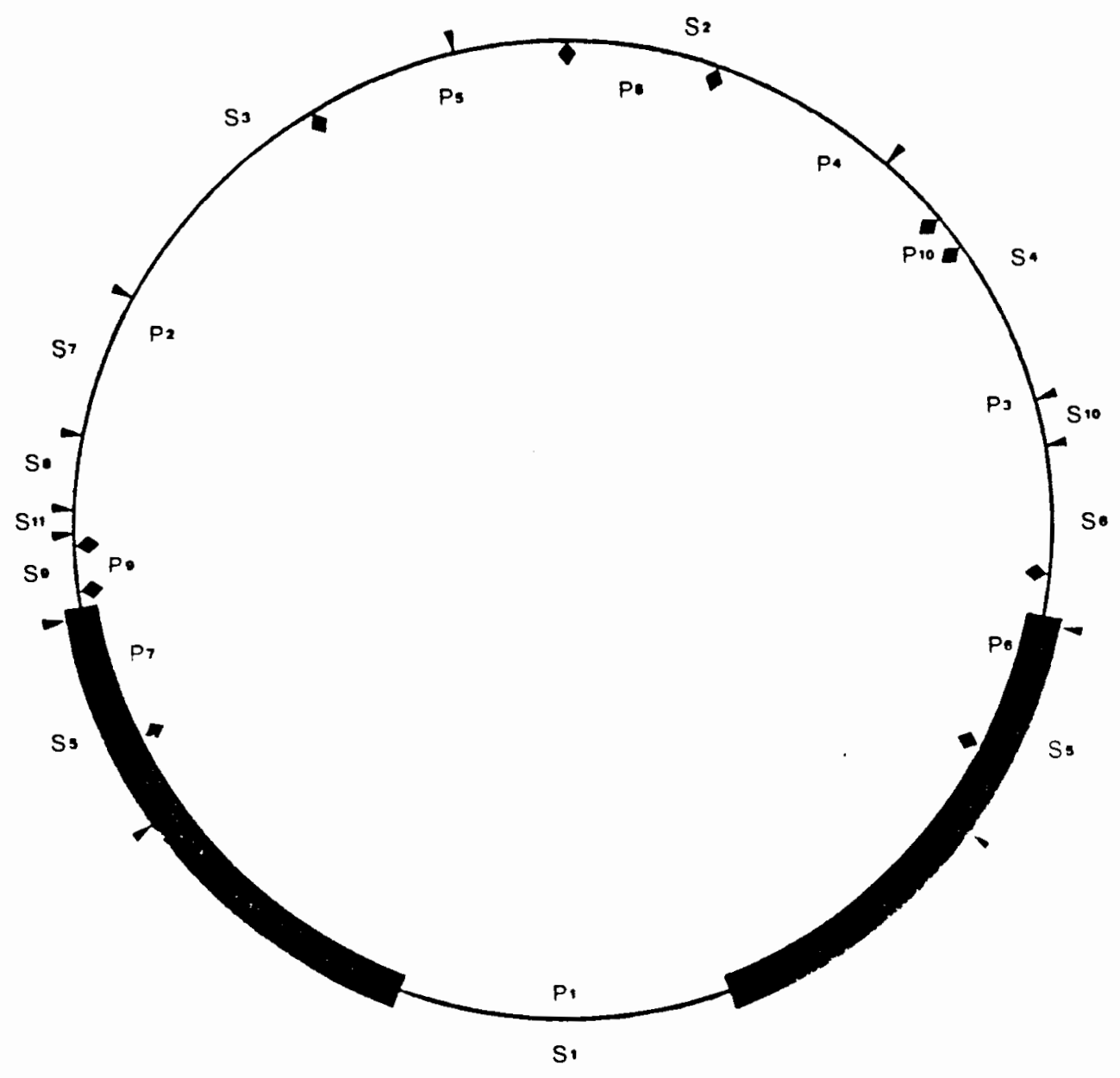

Figure 2. PstI $(\forall)$ and SalI (V) restriction sites of spinach chloroplast genome. 
(Fig. 2). Trangfer RNA genes have been mapped (16) and show a dispersed arrangement. Twenty-one of the thirty-two tRNA species necessary to utilize all possible codons have been identified, and several have been sequenced (5). The tRNAs for Asp. Cys, GIu and GIn have not yet been found on the spinach chloroplast genome. Some identified tRNA genes have been localized only approximately. The ribosomal RNA genes are located in the inverted repeat regions (Fig. 1). The gene arrangement is similar to that of $\underline{E}$. coli addition of a $4.5 \mathrm{~S}$ species between the $5 \mathrm{~S}$ and $23 \mathrm{~S}$ rRA genes (reviewed in 13,18 ).

Although an estimated $80 \%$ of the proteins functioning in the spinach chloroplast are transcribed from nuclear genes, translated on cytoplasmic ribosomes and transported into the organelle $(18,23,24)$ twenty-nine protein genes have been mapped in the chloroplast genome. These include functional proteins in each of the four supramolecular complexes of the photosynthetic membrane, as well as soluble proteins of the Calvin cycle and maintainence proteins. Most of these genes and their flanking regions have been sequenced, and show sequences similar to the -10 and -35 promoter sequences of prokaryotes, although the positions of the promoter regions is variable, the spacing between the promoter regions is consistently 15-19 base pairs (bp). (reviewed in 71). 


\section{Survey of Spinach Ch1oroplesst Protein Genes}

The gene PsbA, coding for the 32 kilodalton (kd) herbicide binding protein of photosystem II has been localized to the Sal fragment \#6 in the large single copy region adjacent to the right inverted repeat, (17). (Eig. 3). The sequence analysis of this gene (74) showed the gene was comprised of 353 codons resulting in a protein with a derived molecular weight (MW) of $38.95 \mathrm{kd}$. The nucleotide sequence shows $95 \%$ homology to that of Nicotiana debneyi and complete amino acid homology. Transcription is counter-clockwise (as the genome is conventionally displayed) and there is a prokaryotic promoter sequence approximately 90 bp upstream of the first ATG start signal. Also present in the 5' flanking region is the putative ribosome binding sequence AAGA at position-10. A sequence in the $3^{\prime}$ flanking region is capable of forming a stable stem-loop structure with a free energy of formation ( $\Delta G$ ) of -34.9 kilocalories (kcal).

The psbB gene coding for the 51 kd p680 reaction center chlorophy11-a apoprotein of photosystem II is located on the sali \#7 fragment (67). The sequence data (49) show an open reading frame of 508 codons and a protein with a derived MW of $56.2 \mathrm{kd}$. The gene is transcribed toward the nearest ( 1 eft) inverted repeat and thus in the same direction as the adjacent genes pets and petD. Promoter sequences are present in the $5^{\prime}$ region and a stem-10op 


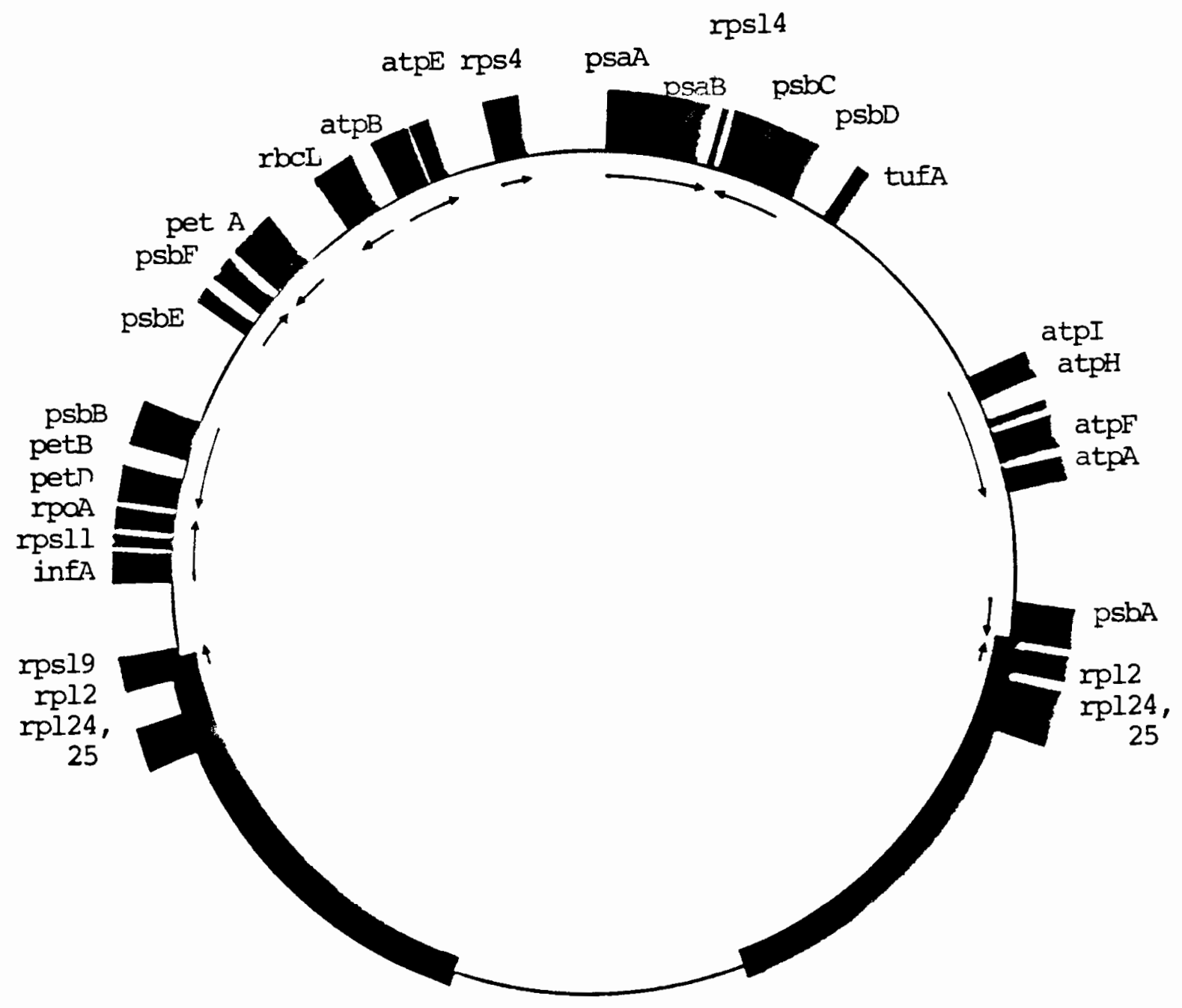

Figure 3. Map of spinach chloroplast genome protein genes. 
sequence $(\triangle G=-41.8 \mathrm{kcal})$ is $300 \mathrm{bp}$ downstream of the TAA stop signal of p틈․

Genes psbc and psbD coding for the $44 \mathrm{kd}$ and D2 proteins of photosystem II, respectively, are located on Pst fragment \#4 (67). Sequence analysis (3, 39) shows that the coding regions overlap by 50 bp, although the reading frames are different. The psbD open reading frame consists of 353 codons resulting in a derived protein of $39.6 \mathrm{kd}$. This protein is $97 \%$ homologous to that of pea and the 160 bp 5' to the ATG codon is $76 \%$ homologous to pea. The psbc gene consists ot 473 codons and begins 50 bp prior to the TAA stop signal of psbD. The derived MW is $51.8 \mathrm{kd}$ and the amino acid sequence is $96 \%$ homologous to pea. The genes psbc and psbD are apparently cotranscribed to a $3.5 \mathrm{~kb}$ RNA species. Transcription is counter-clockwise toward the PstI site between PstI \#4 and \#8 and 21 codons of psbc are within the Pst \#8 fragment (39).

The protein of cytochrome b-559 of photosystem II is thought to consist of two polypeptides coded by genes psbE and PSbE (9,36,70). These genes are located on the SalI \#3 fragment and transcribed toward SaII \#2. The sequence shows pgbE to have 83 codons and a derived protein MW of 8.0 kd. Promoter and ribosome binding sequenes are present, but stem-1oop sequences are absent. Gene psbF has 39 codons, derived protein MW of $4.3 \mathrm{kd}$ and $97 \%$ homology to Nicotiana and Oenothera. In spinach the reading frame is 
shifted from that of psbE and the ATG (methionine) codon follows the PEbE TAG stop signal by 8 bp.

Genes PsaA and PEaB code for two P700 chlorophy11-a apoproteins of photosystem I. These genes are located on Pst fragment \#8 (68) and sequence data (40) show two open reading frames of 750 and 734 codons transcribed clockwise toward $P S \underline{b} C$ and $P S b D$. These open reading frames are separated by a 25 bp spacer and the proteins of derived MW of $83 \mathrm{kd}$ and $82.4 \mathrm{kd}$ are $95 \%$ homologous to those of zea. There are promoter sequences approximately 150-170 bp 5' to the ATG start signal ofpsaA and a stem-1oop sequence ( $G=-9.8 \mathrm{kcal}) 50 \mathrm{bp} 3^{\prime}$ to the TAA stop signal of REaB. These genes are followed closely by the rps14 gene for ribosomal small subunit protein 14. This 100 codon open reading frame follows $121 \mathrm{bp} 31$ to $\mathrm{psaB}$. This third gene is transcribed in the same direction as the other two and is followed by a very stable stem-10op sequence $(\triangle G=-41.4$ kcal). Each of the three genes is preceded by by the possible ribosome binding sequence AGGAGG. This structure suggests a gene group that is transcribed as a polycistronic message.

Gene peta codes for cytochrome $f$ and is located on Sal fragment 3 (2). This may be the only spinach chloroplast coded protein that is translated as a precursor with an N-terminal signal sequence to facilitate insertion of the polypeptide through the thylakoid membrane. This 
conclusion was based on the observations that in 프드으 translation systems produce a protein of $35.3 \mathrm{kd}$. while the protein isolated from chloroplasts is apparently $4 \mathrm{kd}$ or 35 amino acids smaller. The possible ribosome binding sequence GGA is just upstream from the only methionine codon and the putative signal sequence is similar to that of known signal sequences (2). This gene of 320 codons (including $\mathrm{N}$-sequence) is transcribed counter-clockwise toward the psbE and Lsb genes. No clear promoter or stable stem-1oop sequences have been identified.

Genes pet $B$ and petD coding for cytochrome $b$ and subunit 4 are located on the Sal \#8 fragment. Sequence data (32) show the 211 codon petb gene is followed by a $1018 \mathrm{bp}$ spacer prior to the 139 codon petd gene. The two genes are transcribed counter-clockwise, in the same direction as the nearby gene PsbB. PetB and petD are in different reading frames and the derived protein molecular weights are $23.7 \mathrm{kd}$ and $15.2 \mathrm{kd}$, respectively. Each gene is preceded by AAAG ribosome biding sequences and a stem-1oop sequence $(\triangle G=-26.0 \mathrm{kcal})$ follows the TAA stop codon of petD by $30 \mathrm{bp}$.

Genes atp $B$ and atpE coding for the $\beta$ and $\xi$ subunits of the ATP synthase complex are located on the Sali 3 fragment and transcribed clockwise, away from gene rbcL (66). Sequence data (75) show atpB consists of 498 codons with a derived protein MW of $53.9 \mathrm{kd}$. This open reading frame 
overlaps by four codons the 153 codon gene atpe. which is read in a different frame and results in a protein of 14.7 kd derived molecular weight. The amino acid sequences of the $\beta$-subunits of the ATPase complex from E. coli spinach chloroplast are $67 \%$ homologous.

Genes for the ATPase subunits CFo-IV, proteolipid. CFo-I and $C F-\alpha$, atpI, atpH, atpF and atpA, respectively. are grouped on the SalI \#10 and SalI \#4 fragments (69). These genes are transcribed clockwise toward the right inverted repeat in the above order. The sequence of atpI (33) shows an open reading frame of 247 codons and a protein of $27 \mathrm{kd}$ derived MW. This gene is proceded by promoter sequences at -150 and -115 and a GAGG ribosome binding site is at -9. A sequence 300 nucleotides downstream of the TGA stop codon is capable of forming a stem-loop structure. The resultant protein is $28 \%$ homologous to E. coli ATPase subunit-a. A 692 bp spacer follows the stop codon, followed by the 81 codon atpH gene for the proteolipid protein (1). This gene is immediately preceded by a GAGG sequence as well as promoter sequences at positions -100 and -50 . This open reading frame encodes a protein with derived $M W$ of $7.9 \mathrm{kd}$ $100 \%$ homologous to that of wheat. Stem-10op sequences follow at $10 \mathrm{bp}$ and $200 \mathrm{bp} 3^{\prime}$ to the TAA stop codon. Three hundred bp $3^{\prime}$ to the stop codon of atpH, begins gene atpF, which codes for coupling factor CFo-I. This gene is preceded by the GAGG ribosome binding sequence but not by a 
promoter sequence (33). The etpF gene is the only interrupted gene coding for a protein in the spinach chloroplast genome. The first 56 codons are followed by a 714 bp non-translated intron, the coding region then continues for 201 more codons and the protein has a derived MW of $20.9 \mathrm{kd}$. This intron displays all features of class II introns (33). The gene atpA begins 65 bp distal to the atpF stop codon and has not been completely sequenced. The gene rbcl for the large subunit of ribulose 1.5-bisphosphate carboxylase is located at the junction of PstI \#5 and PstI \#2. The sequence (73) shows the direction of transcription is counter-clockwise toward the left inverted repeat, away from the atpB-atpE operon. Promoter sequences are present, as is the GAGG ribosome binding sequence. The open reading frame is 475 codons, resulting in a protein of $52.7 \mathrm{kd}$ and is follwed by a stem-10op sequence $(\triangle G=-16 \mathrm{kcal})$. The amino acid sequence is $90 \%$ homologous to the Zea protein.

Several ribosomal protein genes have been sequenced. rps4, rps11, rps14, rps19, rp12 and two others have been located by other techniques, rp124 and rp125. The gene for the ribosomal small subunit protein 4 , Ips 4 , is located on Sal fragment 2 near the junction with SaII 3 and transcribed clockwise. The sequence (5) shows 201 codons and a protein of $22.9 \mathrm{kd}$ derived MW. Promoter and ribosome binding sequences precede the open reading frame and a 
stem-10op sequence $(\triangle G=-16.6 \mathrm{kcal})$ follows $100 \mathrm{bp}$ after the TAG stop codon. The protein shows $77 \%$ homology to zea and $39 \%$ to E. coli.

The sequence of gene rpsil (59), coding for ribosomal small subunit protein 11 , is located on SalI \#8 and transcribed clockwise. This gene contains 138 codons for a derived protein of $14.9 \mathrm{kd}$ that is $52 \%$ homologous to a ribosomal protein of E. coli. Evidence suggests this gene is cotranscribed with inff and IpoA (see later section).

Gene rps14, 1ocated on PstI \#8, consists of 100 codons and the protein has a derived MW of $12 \mathrm{kd} \mathrm{(40).} \mathrm{This} \mathrm{gene}$ follows the psaB stop codon by 121 bp and is apparently cotranscribed with psaA and PsaB. The AGGA ribosome binding sequence precedes the open reading frame and a stem-1oop sequence $(\triangle G=-41.4 \mathrm{kcal})$ follows the TAA stop codon by 50 bp. The amino acid sequence is $37 \%$ homologous to a ribosomal protein of E. colli.

The genes for ribosomal proteins small subunit 19 and large subunit 2, Ipsig and rpl2, are located at the junctions of the large single copy region and the left and right inverted repeats (76). Gene $\underline{x} 12$ is completely contained within the inverted repeat and is thus represented twice, once on each SalI \#5 fragment. This gene has 286 codons and the protein has a derived MW of $31.8 \mathrm{kd}$. The stop codon TAA is 21 bp before the start of rpsig. This gene spans the junction of the inverted repeat, large single 
copy region and only the open reading frame on the left side has homology to Nicotiana debneyi. This 92 codon gene and the derived $10.6 \mathrm{kd}$ protein is $89 \%$ homologous to that of N. debneyi and $58 \%$ homologous to the E. co1i s19 protein. The gene spanning the right inverted repeat large single copy junction, dubbed rpsl9', is identical to rpsig for the first 48 codons (within the repeat) but the remaining 66 codons are divergent. The derived protein has a MW of $12.5 \mathrm{kd}$. while a stop codon shortens Ips19' in N. debneyi to an open reading frame coding a protein of 3.1 kd. Computer search has shown no E. coli genes with significant homology to Ips19' and the function of this gene remains unknown. As the 5' flanking regions for rps19 and rps19' are identical. they are presumably expressed with equal efficiency.

Two other ribosomal protein genes. rp124 and rp125. have been localized to the sal \$5 fragments of the inverted repeats by cell free transcription-translation and immunoprecipitation (14). No sequence or specific mapping has been reported for these genes. The proteins, large ribsomal subunit 24 and 25 have apparent MW of $13.5-16 \mathrm{kd}$ and $13-14.5 \mathrm{kd}$, respectively, as determined by polyacrylamide gel electrophoresis.

Other proteins for which the genes have been sequenced include initiation factor $I$ and the $\alpha$-subunit of RNA polymerase (59). These genes are located on Pst \#2 near the junction with PstI $\$ 9$, and are cotranscribed clockwise 
with IPS11. The gene Ips11 is located between infA and IpoA. Gene infA consists of 77 codons resulting in a derived protein of $9.1 \mathrm{kd}$, which is $43 \%$ homologous to the E. coli If-1 protein. Gene rpoA has 335 codons and the protein a derived MW of $38.4 \mathrm{kd}$. This gene cluster. infA, rps11. rpoA is followed by a stemm-10op sequence $(\triangle G=-28.2$ kcal) which could also serve as a transcription terminator for the petB-petD transcription unit.

The gene for elongation factor Tu, tuff, has been localized to Pst \#4 of spinach chloroplast genome by hybrization ( 65 ), but has not been sequenced.

In addition, fourteen chloroplast thylakoid membrane protein genes and one soluble protein (ribulose 1,5-bisphosphate carboxylase small subunit) gene which reside on nuclear chromosomes have been characterized (63).

The important features revealed by detailed sequence analysis are the conservation of gene arrangement and protein homology among the chloroplasts of land plants, and the similarities to prokaryotic systems. Selective forces could constrain both the size of the chloroplast genome and gene arrangement. Amino acid sequence conservation of $100 \%$ often occurs between monocotyledons and dicotyledons and there is significant homology from the bryophytes through the angiosperms. Factors that influence this conservation must include the putative control of the chloroplast by the nucleus. This particular chloroplast genome arrangement may 
be necessary for the coordinated expression of the proteins comprising the photosynthetic apparatus. The similarity of the genomes of the chloroplasts of land plants suggests the possibility of a founder effect, only a small population of organelles that assumed this particular genome arrangement survived. Alternatively, other arrangements may have developed but were at some selective disadvantage to the surviving form. That this consistency is the result of convergent evolution seems unlikely.

Evolution of these organelles from ancestors resembling prokaryotes is supported by the similarity seen in the $5^{\prime}$ and $3^{\prime}$ flanking sequences. The consistent presence of promoter, ribosome binding and terminator sequences in chloroplast genes similar to those of E. coli is strong evidence of a common ancestor. One of the main differences between chloroplast genes and those of eubacteria is the occurrence of intervening sequences in both tRNA and protein genes. This may be evidence against common ancestry, or it might be viewed a as secondary development resulting from the interaction between the organelle and the nucleus. Maybe as evolution continues introns will continue to develop in chloroplast genes and these genomes will become less prokaryotic in nature. It has been shown that E. Coli RNA polymerase will bind to spinach chloroplast DNA (72). although not all regions of the genome showed high affinity for the enzyme. 
spinach chloroplast RNA polymerase has been shown to be immunologically similar to the E. coli enzyme (45). Cloned chloroplast genes have been expressed in E. coli using the maxi-cell technique (21), and iㅡ vitro using a highly defined E. colli all chloroplast genes would be expected to be efficiently expressed in E.coli because of the variations in the promoter and terminator sequences. It has also been shown that not all spinach chloroplast tRNA genes require 5' promoter sequences for efficient in vitró transcription using a spinach chloroplast derived transcription system (25, 26).

This work develops a method for spinach chloroplast DNA isolation using the alkaline lysis technique of Birnboim and Doly (6). The goal of chloroplast DNA isolation is to purify high molecular weight chloroplast DNA that is suitable for restriction enzyme digestion and molecular cloning. Chloroplast DNA need not be isolated in circular form for these manipulations, but must be relatively free from nuclear and mitochondrial DNA contamination and be of high molecular weight, $100-150 \mathrm{~kb}$.

Traditional methods of chloroplast DNA isolation use one of three methods to reduce nuclear DNA contamination: DNase treatment, aqueous step-gradients (sucrose or percol1). or nonaqueous gradients $\left(\mathrm{CCl}_{4}\right.$ :hexane) to purify chloroplasts. Mitochondrial DNA contamination is not a 
major problem because mitochondria are easily separated from chloroplasts by differential centrifugation.

\section{Tewari and Kolodner $(41,42)$ separated a crude}

chloroplast pellet from cellular debris by centrifugation. The chloroplast pellet was treated with DNase to eliminate nuclear DNA. DNase was inactivated by protease digestion prior to organelle lysis by SDS. Lysed chloroplasts were extracted with phenol and the DNA precipitated with ethanol. Chloroplast DNA isolated in this manner was examined by electronmicroscopy. approx. $20 \%$ of the sample consisted of circular molecules. No restriction endonuclease digestion or electrophoretic analysis was performed.

Nuclear DNA contamination is caused by DNA from disrupted nuclei adhering to chloroplasts that have lost their outer membranes (54). Separating intact chloroplasts from broken ones by step-gradient centifugation can decrease contamination by nuclear DNA. Aqueous systems use either sucrose (54) or percoll (L. Hanely-Bowdoin personal communication) gradients and nonaqueous systems utilize cc1 :hexane gradients ( 8 ). Once the chloroplasts are recovered from the gradient, they are treated with DNase and/or protease and phenol extracted. These methods are followed by CsCl density gradient centrifugation to further purify the chloroplast DNA.

The method of spinach chloroplast DNA isolation used in this work differs significantly from those just 
described. Chloroplasts were concentrated from a 1 eaf homogenate by centrifugation and contaminating nuclear DNA and proteins were denatured by 1 ysis with alkaline SDS (6) and precipitated with acidified potassium acetate. Residual proteins were removed by phenol:chloroform extraction and RNA reduced by repeated ethanol precipitation in the presence of 2.5 M ammonium acetate. Treatment with DNase, protease, RNase and CsC1 centrifugation were not necessary to recover moderate to good yields $(10-15 \mathrm{ug} / \mathrm{ml})$ of high molecular weight chloroplast DNA. This DNA was suitable for restriction edonuclease digestion, electrophoretic analysis and molecular cloning. 
The following bacterial strains and plasmids were used in this work;

\section{Bacterial straing}

Strain or Plasmid

E. $\operatorname{col} \mathrm{i} \mathrm{K}-12$

Strains

JM 109, JM 105
Relevant Properties

thi, 모L, endA, sbcB15, h8pR4 (1ac-proAB), F', traD36, proAB, lacI, 1 acZ M15

Amp resistance Amp resistance Amp resistance, T7 promoter Amp resistance, T7promoter pUC9+Pst 1 \#5 insert pUC9+Pst 1 \#8 insert pUC9+Pst $1 \# 10$ insert PGEM4+Pst 1 \#5 insert 
The following abbreviations are used in this work;

\begin{tabular}{|c|c|}
\hline a mp & ampicillin \\
\hline b p & base pairs \\
\hline $\mathrm{BPB}$ & bromphenol blue \\
\hline CIA & chloroform: isoamyl a lcohol $24: 1$ \\
\hline EDTA & ethylenediaminetetraacetic acid \\
\hline Et Br & ethidium bromide \\
\hline EtOH & ethanol \\
\hline$F^{\prime}$ & $\begin{array}{l}\text { carrying the E. coli sex factor } \\
\text { F, with a chromosomal insertion }\end{array}$ \\
\hline AEPES & $\begin{array}{l}N-2 \text {-hydroxyethylpiperazine-N }-2 \\
\text { et hanesulfonic acid }\end{array}$ \\
\hline $\begin{array}{l}\text { I P TG } \\
\text { kb }\end{array}$ & $\begin{array}{l}\text { isopropyl- -D-thiogalactoside } \\
\text { kilobases }\end{array}$ \\
\hline $\begin{array}{l}k c a 1 \\
k d\end{array}$ & kilocalories \\
\hline $1 \mathrm{ac}$ & lactose operon \\
\hline LA & Luria agar \\
\hline L. B & Luria broth \\
\hline MCS & multiple cloning site \\
\hline MW & molecular weight \\
\hline SDS & sodium dodecyl sulfate \\
\hline TE & $10 \mathrm{mM}$ Tris pH $8.0,1 \mathrm{mM}$ EDTA \\
\hline TEG & $10 \mathrm{mM}$ Tris pH $8.0,1 \mathrm{mM}$ EDTA, $1 \%$ \\
\hline $\begin{array}{l}\text { Tr is } \\
X-8 \text { a } 1\end{array}$ & $\begin{array}{l}\text { glucose } \\
\text { tris(hydroxymethy } 1 \text { ) aminomethane } \\
5 \text {-bromo-4-chloro-3indolyl- } \\
\quad \text {-D-galactoside }\end{array}$ \\
\hline
\end{tabular}




\section{Isolation of Spinach Chloroplast DNA}

Spinach leaves were purchased at a local produce market. Leaves were torn by hand into $2-5 \mathrm{~cm}$ pieces and the midveins removed. Leaf pieces (200-300 grams) were washed in tap water and blotted dry.

Approximately 75-100 grams of the washed spinach

leaves were placed in a precooled waring blender with $200 \mathrm{~m} 1$ ice cold grinding buffer $(330 \mathrm{mM}$ sorbitol, $50 \mathrm{mM}$ HEPES $\mathrm{PH}$ 8.0. $2 \mathrm{mM}$ EDTA). Leaves were homogenized with three 5 second bursts. A glass stirring rod was used to stir the mixture briefly between bursts. The slurry was filtered through 2 layers of Miracloth (Calbiochem) and collected in a sterile 600 ml beaker over ice. The filtrate was centrifuged in a Sorvall table top centrifuge at $2000 \times g$ for one minute at room temperature. The crude chloroplast pellet was washed 2 times in 30 m1 grinding buffer. resuspended in $10 \mathrm{~m} 1$ of the same and held on ice.

Twenty $m 1$ of alkaline SDS $(0.2 \mathrm{~N} \mathrm{NaOH}, 1 \% \mathrm{SDS}),(6)$. was added to the chloroplast suspension, which was mixed gently and kept on ice for 5 min. Ten ml of a solution of 5 Macidified potassium acetate $(60$ m1 5 M potassium acetate, $11.5 \mathrm{ml}$ glacial acetic acid, $28.5 \mathrm{ml} \mathrm{H}_{2} \mathrm{O}$ ), (47), was added and mixed by pouring the solution gently back and forth beween two $40 \mathrm{~m} 1$ centrifuge tubes. The mixture was placed on ice for 15 min then centrifuged in a ss-34 rotor at $12,000 \times g$ for 30 min at $4^{\circ} \mathrm{C}$. The supernatent was poured 
through two layers of cheesecloth into a 150 ml Corex centrifuge bottle and 0.6 volumes isopropanol was mixed in by gentle inversion. The nucleic acids were precipitated on ice for one hour and collected by centrifugation at $12,000 \times 8$ for $30 \mathrm{~min}$ at $4^{\circ} \mathrm{C}$. The pellet was resuspended in $0.5 \mathrm{~m} 1 \mathrm{TE}$. Spinach chloroplast DNA was either digested by restriction endonucleases or further purified by the following procedure. The DNA solution was extracted with an equal volume phenol:CIA and the phases separated by one minute centrifugation in a Beckman Microfuge-B. The aqueous phase was removed with a micropipette to a clean microfuge tube. made $2.5 \mathrm{M}$ with ammonium acetate and the DNA precipitated by adding 2.5 volumes $95 \%$ EtOH on ice for 30 min. The precipitate was collected by 10 min microcentrifugation at $4^{\circ} \mathrm{C}$. The ammonium acetate:EtOH precipitation was repeated and the final DNA pellet resuspended in 100 ul TE.

Restriction Analysis of Spinach Chloroplast DNA

Twenty-six ul of spinach chloroplast DNA (250 ng) was mixed with 3 ul $10 x$ restriction buffer (salt concentration appropriate to specific enzyme) and 1 ul restriction enzyme (10 units/ul). The reaction mixture was incubated at $37^{\circ} \mathrm{C}$ for 2 hours and the reaction stopped by heating to $68^{\circ} \mathrm{C}$ for 10 min. Four ul reaction mixture or 4 ul intact DNA sample was mixed with 1 uI DNA tracking dye (40\% sucrose, $1.0 \%$ SDS, $0.25 \%$ BPB). Samples were loaded into wells of a $0.7 \%$ agarose horizontal slab gel and electrophoresis carried out 
at 75 volts. 40 milliampres for 2 hours in Tris-acetate buffer (47). Gels were stained in 1 ug/m1 EtBr for 15-30 min and destained under runnning tap water for 15 min. DNA bands were visualized by placing the destained gel on an ultraviolet transilluminator. Gels were photographed with a Polaroid MP-4 Land camera using a Kodak $22 \mathrm{~A}$ Wratten filter and Polaroid type 57 direct positive film. DNA concentration was estimated by comparison of band f1uorescence with known DNA concentrations.

Cloning of Spinach Chloroplast DNA into PUC P1asmids Approximately 0.5 ug vector DNA (pUC8 or pUC9) was digested with restriction enzyme PstI as previously described. Ten ul $10 x$ calf intestinal alkaline phosphatase buffer $\left(0.5 \mathrm{M}\right.$ Tris $\left.\mathrm{pH} 9.0,10 \mathrm{mM} \mathrm{MgSO}, 1 \mathrm{mM} \mathrm{ZnSO}_{4}\right),(47)$, 0.5 ul calf intestinal alkaline phosphatase (19 units/u1) and 59 u1 $\mathrm{H}_{2} \mathrm{O}$ were added to the 30 ul restriction reaction for a final volume of 100 ul. This mixture was incubated at $37^{\circ} \mathrm{C}$ for 30 min then another 0.5 ul calf intestinal alkaline phosphatase was added and the incubation continued for an additional $30 \mathrm{~min}$. The reaction mixture was heated to $68^{\circ} \mathrm{C}$ for 10 min and extracted with one volume phenol:CIA. After centrifugation the aqueous phase was removed to a clean microfuge tube and the organic phase re-extracted with 100 ul TE to maximize DNA recovery. The two aqueous phases were pooled. made $2.5 \mathrm{M}$ with ammonium acetate and the DNA precipitated with 2.5 volumes $95 \%$ EtoH on ice for 30 min. 
The precipitate was collected by 10 min centrifugation at $4^{\circ} \mathrm{C}$. The supernatent was poured off and the DNA pellet allowed to drain and air dry for 30 min. The DNA was resuspended in 20 ul TE.

Restriction enzyme digested spinach chloroplast DNA ( $100 \mathrm{ng}$ ) was made up to 100 ul total volume and extracted with phenol:CIA as previously described. The DNA was precipitated with $2.5 \mathrm{M}$ ammonium acetate:EtoH and resuspended in 7 ul TE. This 7 ul aliquot was mixed with 1 ul alkaline phosophatase treated plasmid DNA, the insert:vector ratio was approximately $3: 1$. The mixture was heated to $65^{\circ} \mathrm{C}$ for 5 min to free sticky ends and cooled to room temperature. One ul $10 \times 1$ igation buffer $10.66 \mathrm{M}$ Tris $\mathrm{pH} 7.5,50 \mathrm{mM} \mathrm{MgSO}, 50 \mathrm{mM}$ dithiothreitol, $10 \mathrm{mM} \mathrm{ATP),} \mathrm{(47).}$ and 0.5 ul T4 DNA 1 igase ( 1 unit/ul) was added to the DNA mixture and stirred carefully with a micropipette tip. The 1 igation was carried out at $16^{\circ} \mathrm{C}$ for 12 hours followed by 4 hours at $4^{\circ} \mathrm{C}$. As restriction and ligation controls, samples of alkaline phosphatase treated plasmid DNA were incubated in the same manner, with and without T4 DNA 1 igase.

Competent cel1s, E. coli JM 105, were prepared by the $\mathrm{CaCl}_{2}$ procedure (47). Early 108 phase ce11s were held on ice for 15 min, collected by centrifugation at $3000 \times g$ for 5 min at $4^{\circ} \mathrm{C}$, resuspended in $1 / 2$ volume ice cold, sterile $\mathrm{CaCl}_{2}$ and held on ice for 10 min. The cells were recentrifuged as above and resuspended in $1 / 15$ volume $\mathrm{CaCl}_{2}$. Aliquots of 
100-200 ul were pipetted into sterile, prechilled tubes and stored at $4^{\circ} \mathrm{C}$ for $12-24$ hours.

Transformation of competent cells to ampicillin

resistance was performed by adding 5 ul ligation mixture or controls to cell aliquots. The cells were incubated on ice for $30 \mathrm{~min}$, heat shocked to $42^{\circ} \mathrm{C}$ for 2 min, returned to ice for 2 min then allowed to warm to room temperature. Onem 1 LB was added to each transformation mixture and the cells were incubated at $37^{\circ} \mathrm{C}$ for 2 hours with occasional gentle shaking.

Aliquots of each transformation mixture, 0.1-0.2 m1. were spread on ampicillin. IPTG, X-gal plates $(50$ ug/ml amp, $0.003 \% \mathrm{X}-\mathrm{ga}, 40 \mathrm{MM}$ IPTG). The plates were incubated at $37^{\circ} \mathrm{C}$ overnight.

\section{Identification of C1oned Spinach DNA Fragments}

White transformant colonies resulting from the insertion of spinach chloroplast DNA into the MCS of the pUC plasmid and the $10 s$ of $\beta-g a l a c t o s i d a s e$ activity were streaked onto LA-amp plates ( 50 ug amp/m1). incubated overnight at $37^{\circ} \mathrm{C}$ and isolated colonies used to inoculate 150 ml LB-amp cultures. Cells were grown overnight at $37^{\circ} \mathrm{C}$ with vigorous shaking. The cells were collected by centifugation and the plasmids harvested by the alkaline lysis method of Birnboim and Doly. (6). The cells (1-2 grams) were resuspended in $10 \mathrm{ml}$ TEG, transferred to a $40 \mathrm{ml}$ centrifugetube and held on ice for 10 min. Cells were lysed 
by the addition of $20 \mathrm{ml} 0.2 \mathrm{~N} \mathrm{NaOH}, 1 \% \mathrm{SDS}$, gentle mixing and incubation on ice for 15 min. Ten ml of 5 M acidified potassium acetate was added, mixed by gentle inversion and the mixture beld on ice for 15 min. Proteins and other cellular debris were collected by centrifugation at $12.000 \times g$ for 30 min at $4^{\circ} \mathrm{C}$ in an SS-34 rotor. The supernatent was poured through two layers of cheesecloth into a clean $150 \mathrm{ml}$ Corex centrifuge bottle, 0.6 volumes isopropanol mixed in by inversion and the nucleic acids precipitated on ice for one hour or overnight at $-20^{\circ} \mathrm{C}$. The precipitate was collected by centrifugation at $12.000 \times 8$ for 30 min at $4^{\circ} \mathrm{C}$, the supernatent was discarded and the pellet resuspended in $T E$ to a total volume of $6 \mathrm{ml}$. The nucleic acid solution was poured into a $10 \mathrm{ml}$ Beckman polypropylene ultracentrifuge tube and 6 grams CsCl was added. The tubes were sealed with parafilm and gently inverted 10 times to dissolve the CsCl. Protein debris floating to the top was removed with a sterile cotton swab. To each tube, $0.5 \mathrm{ml}$ EtBr $(10 \mathrm{mg} / \mathrm{ml})$ was added and mixed by inversion. The tubes werefilled to the top with mineral oil and sealed with aluminum caps.

Cesium chloride density gradient centrifugation was carried out in a Beckman $L-2$ 65B ultracentrifuge using a Ti 50 rotor at $45,000 \mathrm{rpm}$ for $36-48$ hours at $20 \mathrm{C}$. The resultant DNA bands were visualized with long wavelength ultraviolet light and the lower band, representing covalently closed circular DNA, was removed by inserting a 
16 gauge needle through the tube just below the band and drawing the band into a 3 ml disposable plastic syringe. The sample (1-2 m1) was placed in a 15 m1 Corex centrifuge tube and the EtBr removed by repeated extraction with isopropanol saturated with $5 \mathrm{M} \mathrm{NaCl}$ and TE. Once the EtBr was removed, 2 volumes distilled $\mathrm{H}_{2} \mathrm{O}$ and 6 volumes $95 \%$ EtOH were added and the DNA precipitated on ice for one hour or at $-20^{\circ} \mathrm{C}$ overnight. The DNA was collected by centifugation at $12.000 \times g$ for 30 min at $4^{\circ} \mathrm{C}$, and the pellet resuspended in 200 u1 TE. The DNA was further purified by $1-2$ additional EtoH precipitations in the presence of 2.5 M ammonium acetate.

These samples were diluted $1: 100$ and digested with the enzyme used for the original cloning. Pst, and by Sall, as described previously. The restriction digests were analyzed by agarose gel electrophoresis and DNA fragments sized by comparison to the HindIII restriction fragments of bacteriophage $\lambda$ DNA. In most cases the salI digests of the recombinant plasmids facilitated the identification of the cloned spinach chloroplast DNA fragment and showed the orientation of the fragment in the Pst site of the pUC plasmid MCS.

Some spinach chloroplast DNA fragments were difficult to identify by sizing and sall digestion. These recombinant plasmids were digested with other enzymes whose restriction sites are mapped on the spinach chloroplast genome. The 
ClaI sites in Pst fragment $\$ 5$ were mapped by single digestion with Clal and sequential digestion with ClaI and then SalI.

\section{Subcloning the PstI 15 Fragment in PGEM4}

The Pst $\$ 5$ fragment of spinach chloroplast DNA was subcloned into plasmid pGEM4 by the following procedure, (15). A 52 ul sample of the recombinant plasmid pRD 305 (200 ng DNA) was mixed with 6 ul $10 x$ restriction buffer and 1 ul restriction enzyme PstI ( 10 units/u1) and incubated at $37^{\circ} \mathrm{C}$ for 2 hours. The digestion was stopped by heating to $68^{\circ} \mathrm{C}$ for 10 min. DNA tracking dye (15 ul) was added and the sample was micropipetted into an oversized well in a $0.7 \%$ agarose gel. The oversized well was formed by taping 6 teeth of the well forming comb together and the agarose was poured containing 1 ug/ml EtBr. The sample was electrophoresed at 75 volts for one hour, the gel removed from the electrophoresis apparatus and visualized on an ultraviolet transilluminator. The band representing the spinach chloroplast PstI \#5 fragment was located and an incision made with a razor blade just in front of the DNA band. A piece of Whatman DE 81 DEAE cellulose paper the same length as the oversized well and $3 \mathrm{~mm}$ wide was placed on edge in the incision. The gel was carefully slid back onto the gel tray and replaced in the electrophoresis tank. The voltage was raised to 100 volts for 15 min. The gel was again removed to the ultraviolet translilluminator and the 
fluorescence was shown to be on the paper rather than in the 8e1. The paper was removed and placed in the barrel of a 3 ml disposable plastic syringe. The syringe was placed in a 15 ml Corex centrifuge tube and the paper washed by pipetting $200 \mathrm{ul} 0.1 \mathrm{M} \mathrm{NaCl}, 50 \mathrm{mM}$ Tris pH $8.0,0.1 \mathrm{mM}$ EDTA into the syringe and centrifuging the tube at $2000 x g$ for one min. This process was repeated once. The wash that was collected in the corex tube was discarded. A microcentrifuge tube was placed over the end of the syringe and the DNA was eluted from the paper by pipetting 100 ul 1.0 M NaCl, $50 \mathrm{mM}$ Tris $\mathrm{pH} 8.0 .0 .1 \mathrm{mM}$ EDTA into the syringe and letting it stand at room temperature for 15-20 min. The eluate was collected in the microcentrifuge tube by centrifugation at $2000 \times g$ for one minute. This process was repeated three times. The DNA was precipitated from the 400 ul total eluate by adding 1 ml $95 \%$ EtoH and placing the tube on ice for 30 min or at $-20^{\circ} \mathrm{C}$ overnight. The DNA was pelleted by 10 min microcentrifugation at $4^{\circ} \mathrm{C}$ and the sample resuspended in 100 ul TE, extracted with phenol: CIA and precipitated with EtOH in the presence of $2.5 \mathrm{M}$ ammonium acetate. The DNA was resuspended in 7 ul TE and the Iigation into pGEM4 was done as described previously. 
RESULTS

\section{Spinach Chloroplast DNA Isolation}

High molecular weight spinach chloroplast DNA was obtained by alkaline lysis and precipitation in isopropanol. The yield was approximately 50 ug chloroplast DNA per 100 grams starting leaf material. The DNA consisted of $90 \%$ linear molecules $(100-150 \mathrm{~kb})$ and $10 \%$ open circular molecules, as determined by agarose gel electrophoresis, (Fig. 4). Upondigestion with restriction enzyme Sall, the circular and high molecular weight bands disappear and bands representing 10 of the 11 restriction fragments are visible, (Fig. 4). The band representing the smallest fragment, $(0.50 \mathrm{~kb})$ could not be seen. A large amount of RNA is also present in the preparation.

After further purification by repeated EtoH:ammonium acetate precipitation, most of the RNA was removed (Fig. 5). There was also a significant loss of DNA during this procedure. The yield was reduced to approximately 20 ug chloroplast DNA per 100 grams starting leaf material.

Cloning of Spinach Chloroplast DNA into pUC Plasmids Transformation of E. colí JM 105 cells to ampicillin resistance with a Pst digested chloroflast DNA-puC9 ligation mixture typically resulted in 100-200 resistant colonies per 0.1 ml cell suspension spread on amp, IPTG, 


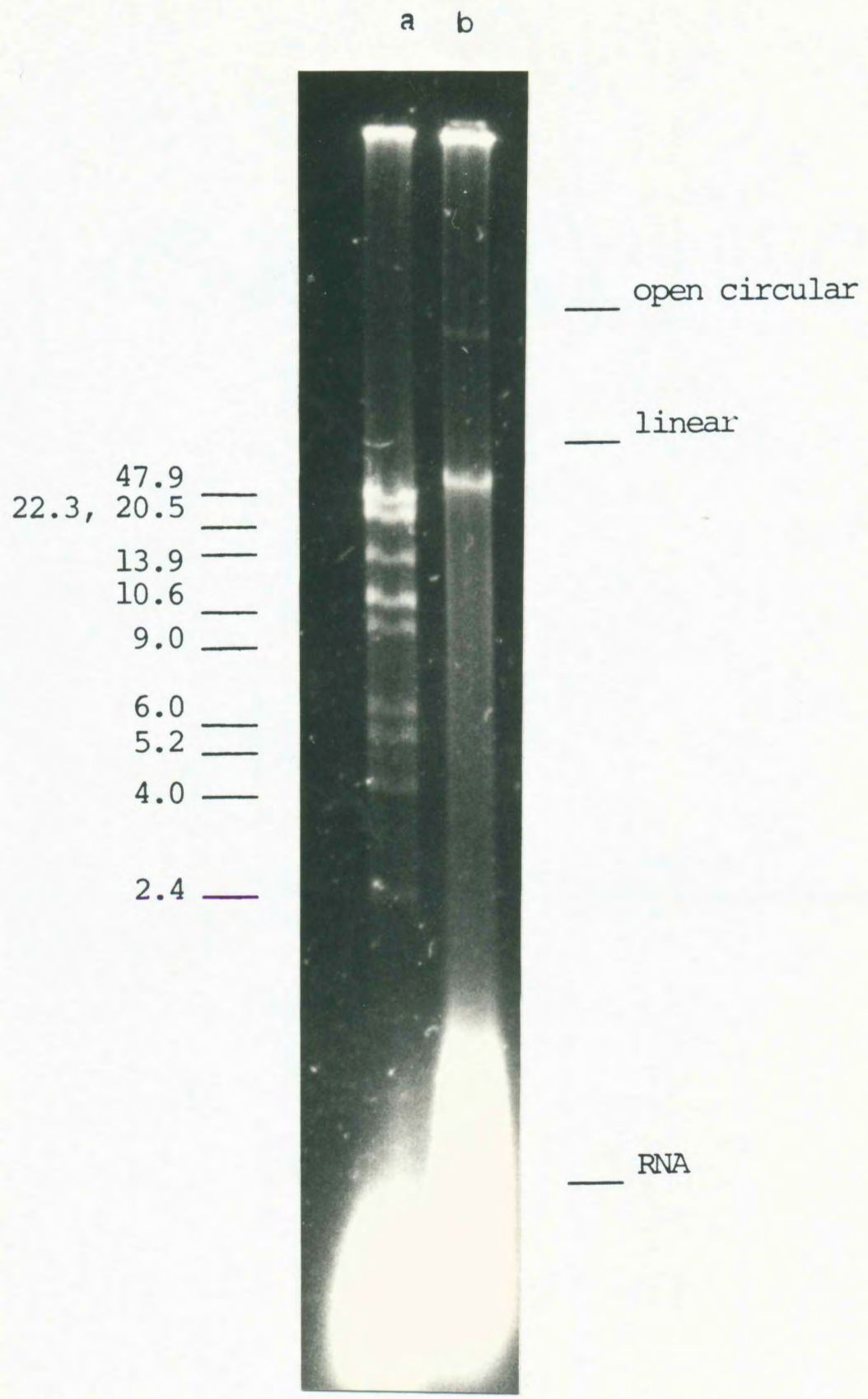

Figure 4. Spinach chloroplast DNA isolated by alkaline lysis, digested with SalI (lane a), undigested (lane b). Fragment molecular weights shown at left in $\mathrm{kb}$. 


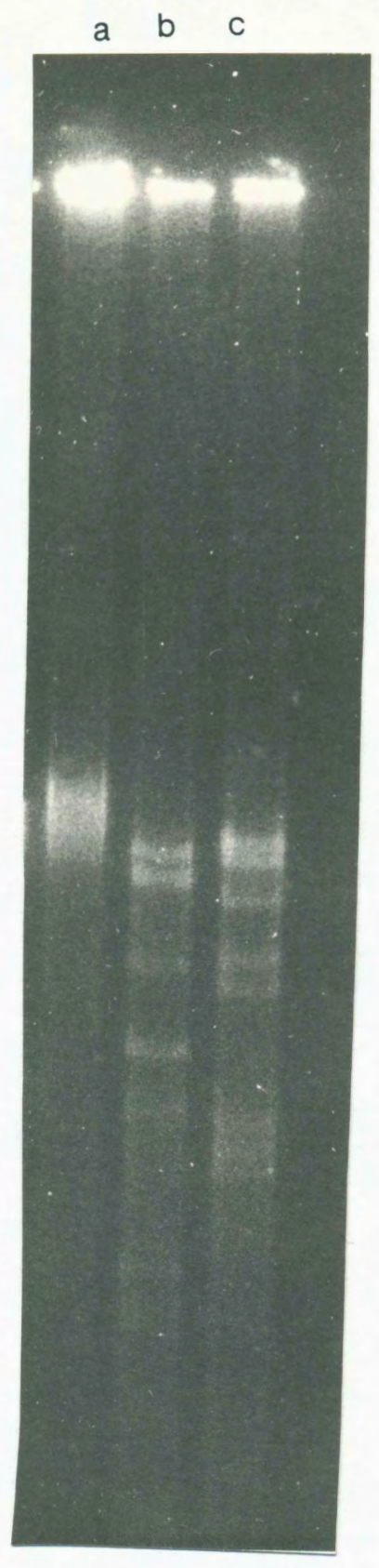

Figure 5. Agarose gel electrophoresis of spinach chloroplast DNA isolated by alkaline lysis and purified by repeated EtOH:ammonium acetate precipitation, undigested (lane a), digested with SalI (lane b) and digested with PstI (lane c). 
X-gal LA plate. Twenty percent of these colonies were white, showing insertion into the MCS of puCg and $10 \mathrm{~s}$ of -galactosidase activity. The rest of the colonies were blue. Control plates showed 100-200 blue colonies and no white colonies when ligation mixtures containing puc9 digested by Pat and treated with alkaline phosphatase were incubated with T4 DNA 1 igase and no transformants if the T4 ligase was omitted.

\section{Identification of Cloned Chloroplast DNA Eragments}

All white colonies screened contained plasmids larger than puc9 (data not shown). Several clones were selected for identification of the inserted chloroplast DNA fragment. Digestion of recombinant plasmids with Pst showed bands corresponding to the pUC plasmid and inserts of $1.9 \mathrm{~kb}, 7.7 \mathrm{~kb}$ and approximately $12.0-13.0 \mathrm{~kb}$ (Fig \#6). These inserts were tentatively identified as spinach chloroplast DNA Pst fragments $\$ 10, \# 8$ and $\$ 5$. respectively, on the basis of molecular weight. The recombinant plasmids were designated PRD110, pRD108 and pRD105 according to the convention established by Alt, et al (1). When the recombinant plasmids were digested with SalI, pRD110 showed a single band of $3.3 \mathrm{~kb}$ and pRD108 a single band of $10.1 \mathrm{~kb}$ (Fig. 6). This shows that niether of these inserts has a Sal site, the single site in the recombinant plasmids represents the site in the MCS of the puC plasmid, and supports the identification assigned. Recombinant plasmid 
pRD105 shows two bands of $5.0 \mathrm{~kb}$ and $10 \mathrm{~kb}$ upon Sal digestion (Fig, 6). Therefore, there is one sall site in the insert. Both PotI fragment $\$ 4,13.5 \mathrm{~kb}$ and Pst fragment $\$ 5,12.3 \mathrm{~kb}$ have one sal site in the same relative position (Fig. 3). Sequence data of these fragments show PstI \$4 has 3 BamHI sites, (39), and PstI \#5 has only one (67). Digestion of pRD105 resulted in fragmenta of $9.5 \mathrm{~kb}$ and $5.5 \mathrm{~kb}$ and demonstrates that the insert has only one Bami site and therefore must be Pst \#5 (Fig. 6. 1ane h). Subcloning of PstI \#5 into pGEM4

Transformation of JM 109 to ampicillin resistance with PatI \#5 1 igated into pGEM4 on amp, IPTG, X-gal plates resulted in 20-30\% white colonies. Examination of the recombinant plasmids by electrophoresis after Pst and SalI confirmed the insertion of Pst \#5 into pGEM4 (data not shown). The recombinant plasmid was designated pRG105.

\section{Mapping of C1aI Sites in PstI \#5}

Digestion of pRD105 with C1aI resulted in fragments of $9 \mathrm{~kb}$ and $6 \mathrm{~kb}$ (Fig. 7). There are no ClaI aites in puC9, thus there are two recognizable ClaI sites in PstI\#5. The ClaI recognition sequence. ATCGAT, contains three (GAT) of the four (GATC) bases of the dam DNA methylation sequence and it is possible that there are other ClaI sites, preceded by G or followed by C that are mehtylated in a damt strain such as JM 109. These sites cannot be recognized by ClaI. Seqential digestion of PRD105 with ClaI and SalI reauled in 


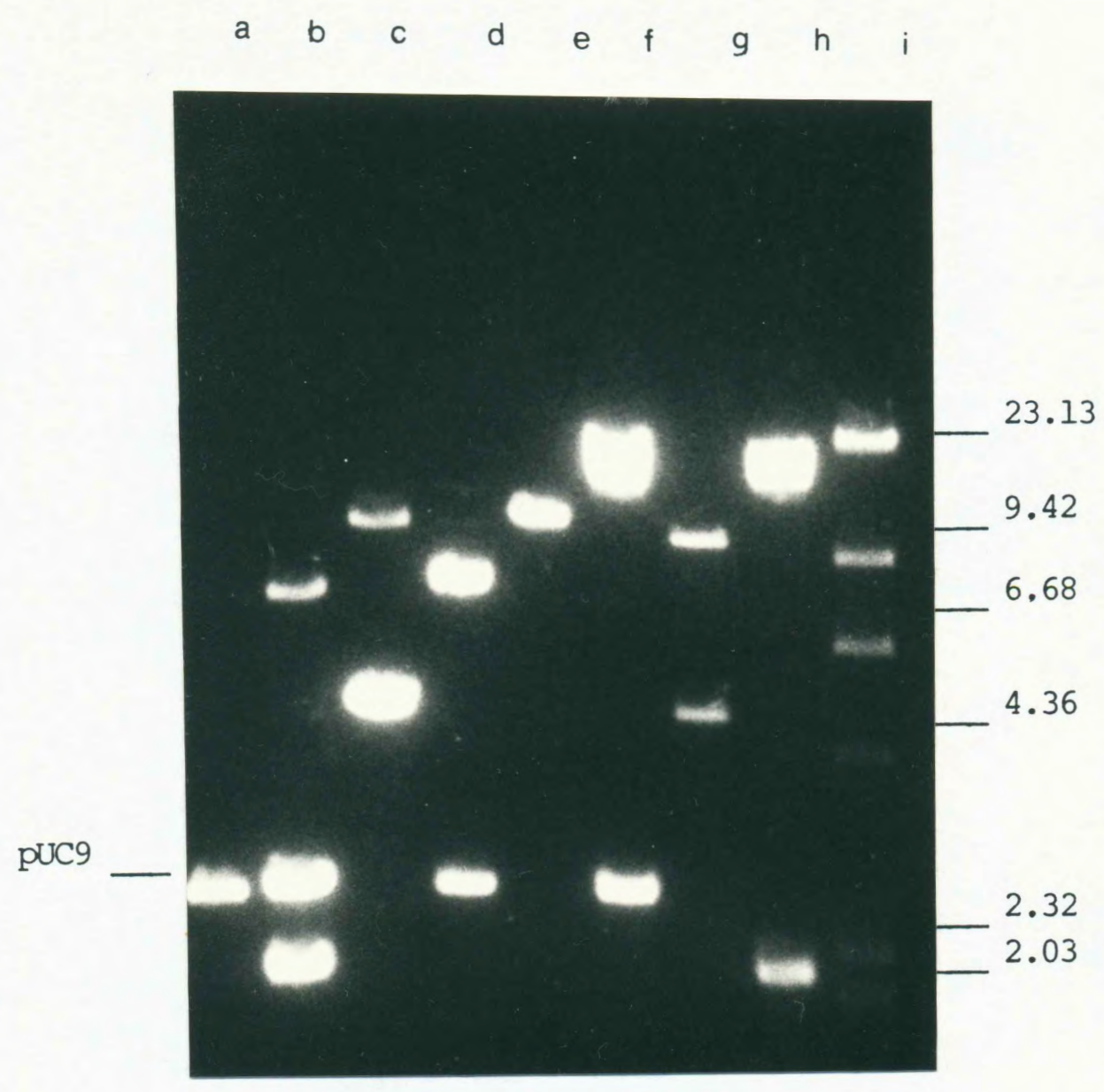

Figure 6. Electrophoretic analysis of recombinant plasmids pRD110, pRD108 and pRD105. pUC9 digested with PstI (lane a). pRDIl0 digested eith PstI (lane b) and SalI (lane c). pRDl08 digested with PstI (lane d) and SalI (lane e). pRDl05 digested with PstI (lane f), SalI (lane g) and BamHi (lane h). $\lambda$ DNA digested with HindIII (lane i), molecular weights shown at right in $\mathrm{kb}$. 


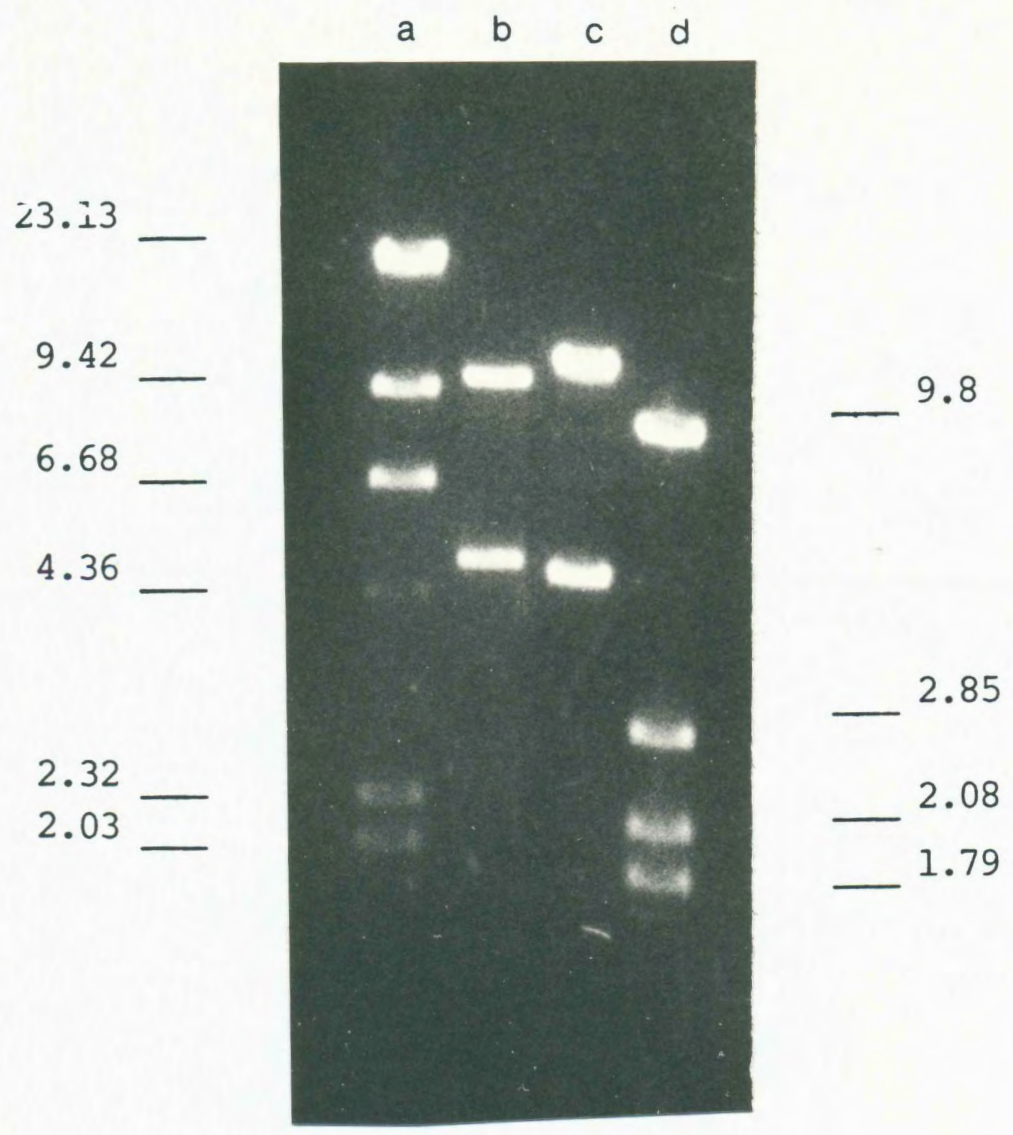

Figure 7. Electrophoretic analysis of ClaI digestion of pRD105. HindIII digestion of $\lambda$ DNA (lane a), with molecular weights shown at left in kb. pRDl05 digested with SalI (lane b), ClaI (lane c) and SalI+ClaI (lane d). Molecular weights of double digestion fragments shown at right in $\mathrm{kb}$. 
four fragments of $1.8 \mathrm{~kb}, 2.1 \mathrm{~kb}, 2.9 \mathrm{~kb}$ and $8.6 \mathrm{~kb}$ (Fig. 7). The positions of the recognized Clal sites in PstI 5 have been mapped (Fig. 8). 


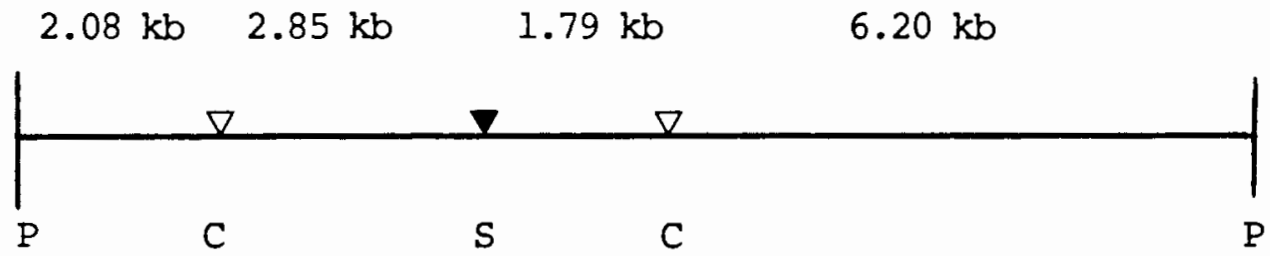

Figure 8. Positions of ClaI restriction sites in spinach chloroplast genome PstI fragment \#5. 


\section{DISCUSSION}

Isolation of spinach chloroplast DNA by alkaline lysis is a quick and convenient method. The 2-3 hour preparation time is much less than most methods because no step gradients are necessary to isolate intact chloroplasts and no CsC1 centrifugation is used to purifiy the DNA. No plants need to be grown ahead of time as commercially available spinach leaves give reasonable yields. This method probably works because alkaline conditions ( $p H$ 12.0-12.5) denature the 1 inear nuclear DNA. The nuclear DNA consists of large linear molecules after cell homogenization and organelle lysis, while much of the chloroplast DNA is still circular. When the lysate is neutralized by acidic potassium acetate, most of the nuclear DNA aggregates to form an insoluble network while the circular chloroplast DNA stays in solution. The high potassium acetate concentration also causes the precipitation of the protein-SDS and chlorophy11-protein-SDS complexes. Therefore, most of the contaminating macromolecules may be removed in one centrifugation. The remaining proteins and RNA are effectively reduced by the phenol:CIA extraction and repeated EtOH:ammonium acetate precipitations.

Most of the chloroplast DNA does not survive as covalently closed circular molecules. This might be due to 
mechanical shear forces during cell homogenization and subsequent handing or the presence of 10-20 ribonucleotide substitutions found in spinach chloroplast DNA (reviewed in 4). Alkaline conditions would be expected to degrade DNA at these ribonucleotide sites, but Maniatis et al report that alkaline 1 ysis results in 1 ess than $5 \%$ nicked plasmid molecules when ribonucleotide substitution is induced by plasmid amp1ification by chloramphenico1, (47 p. 91). The chLoroplast DNA shows consistently good restriction patterns, so there must be very few breaks per DNA molecule. The ability of these fragments to be cloned into plasmid vectors attests to their integrity. The disadvantage of this procedure is that the yield is less than the $100 \mathrm{~g} / 100 \mathrm{~g}$ starting leaf material reported by palmer (54).

The JM 105 pUC cloning system uses a histochemical assay of $\beta$-galactosidase activity to indicate insertion of a DNA fragment into the MCS of the plasmid. The puC plasmid carries a portion of the lacz gene whose product complements the detective $\beta$-galactosidase encoded by th F' borne in JM 105 (64). If the puC plasmid is intact, a functional 8-galactosidase results. This is demonstrated by induction with IPTG and cleavage of $x-g a 1$ to an insoluble b1ue dye. If there is an insertion into the MCS of the plasmid. no functional $\beta-g a 1 a c t o s i d a s e$ is formed and $x-8 a 1$ is not cleaved. Therefore, blue colonies show an intact plasmid 
and white colonies signify an insertion into the MCs of the pUC plasmid.

The cloning procedures showed a high background of blue colonies, this could be caused by incomplete digestion of the plasmid or by recirculaization of the digested plasmid. No colonies were observed on plates spread with cells transformed by digested plasmid DNA incubated without T4 DNA 1igase, so incomplete digestion can be ruled out. The only other explanation of the numerous blue colonies is that the dephosphorylation was ineffective and there was recircularization of digested plasmid DNA. Several different buffers were tried and the most likely explanation is the calf intestinal phosphatase was defective or inactivated in some way.

The PstI \#5 spinach chloroplast DNA fragment was subcloned into the plasmid pGEM4 because this plasmid has promoters for bacteriophage SP6 and T7 RNA polymerases.

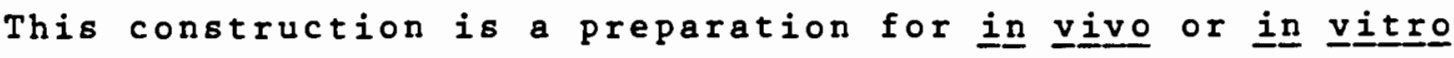
transcription/translation studies. Experiments of this type might be used to study the mechanisms that control expression of chloroplast genes or possibly to express open reading frames that have not yet been identified. Expression of these open reading frames and production of the coded polypeptide might be one method of identifying the protein when there is insufficient homology to E. coli proteins for identification. 
In summary, a new method of spinach chloroplast DNA isolation has been developed. This method is quicker and easier than methods currently in use and yields reasonable quantities of DNA that is suitable for cloning and amplification. Several recombinant plasmids have been constructed and identified and the Pst \#5 fragment has been inserted into plasmid pGEM4 in preparation for transcription/translation studies. 


\section{REFERENCES}

1. Alt, J.. Winter, P., Sebald, W., Moser, J.G.. Schedel, R., Westoff, P. and Herrmann, R.G. (1983). Localization and Nuceleotide sequence of the Gene for the ATP Synthase Proteolipid Subunit on the Spinach Plastid Chromosome. Curr. Genet. 7:129-138.

2. A1t, J. and Herrmann, R.G. (1984). Nucleotide Sequence of the Gene for Pre-apocytochrome $f$ in the spinach Plastid Chromosome. Curr. Genet. 8:551-557.

3. Alt, J., Morris, J., Westoff, P. and Herrmann, R.G. (1984). Nucleotide Sequence of the Clustered Genes for the $44 \mathrm{kd}$ Chlorophyll Apoprotein and the "32kd"-like Protein of the Photosystem II Reaction Center in the Spinach Plastid Chromosome. Curr. Genet. 8:597-606.

4. Bedbrook, J.R. and Kolodner, R. (1979). The Structure of Chloroplast DNA. Ann. Rev. Plant Physiol. 30:593-620.

5. Ben Tahar, S., Bottomley, W. and Whitfield, P.R. (1986). Characterization of the Spinach Chloroplast Genes for the S4 Ribosomal Protein, tRNAthr (UGU) and tRNAser (GGA). P1ant Mol. Bio1. 7:63-70.

6. Birnborm, H.C. and Doly, J. (1979). A Rapid Alkaline Extraction Procedure for Screening Recombinant Plasmid DNA. Nuc. Acidg Res. 7(6):1513-1523.

7. Bogorad, L., Regulation of Intracellular Gene Flow in

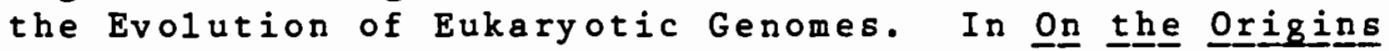
of Chloroplasts. Schiff, J.A., ed. Elsevier North Holiand, Inc., New York, 1982 .

8. Bowman, C.M. and Dyer. T.A. (1982). Purification and Analysis of DNA from Wheat Chloroplasts Isolated in Nonaqueous Media. Analytical Biochem. 122:108-118.

9. Carril10, N., Seyer, P. Tyagi, A. and Herrmann, R.G. (1986). Cytochrome b-559 Genes from Oenothera hookeri and Nicotiana tabacum Show a Remarkab̄y High Degree of Conservation as Compared to Spinach. Curr. Genet. $10: 619-624$. 
10. Cocking, E.C., Davey, M.R., Pental, D., and Power, J.B.. (1981). Aspects of P1ant Genetic Manipulation. Nature $293: 265-270$.

11. Cohen, B.N., Coleman, T.A., Schmitt, J.J. and Weissbach. H. (1984). In vitro Expression and Characterization Start Site of the psbA Gene Product (QB Protein) from Higher Plants. Nuc. Acids Res. $12(15): 6221-6230$.

12. Courtice,G.R.M., Bowman, C.M. Dyer, T.A. and Gray. J.C. (1985). Localisation of Genes for Components of Photosystem II in Chloroplast DNA from Pea and wheat. Curr. Genet. 10:329-333.

13. Crouse, E.J., Bohnert, H.J. and Schmitt, J.M. Chloroplast RNA Synthesis. In Chloroplast Biogenesis, E1Iis. R.J.. ed. Cambridge University Press, Cambridge. 1984 .

14. Dorne, A.M., Heizman, D.. Alt, J. and Mache, R. (1985). Spinach Chloroplast Genes Coding for Three Ribosomal Proteins. Mol. Gen. Genet. 198:521-524.

15. Dretzen, G.. Bellard, M. Sassone-Corsi, P. and Chambon, P. (1981). A Reliable Method for the Recoverey of DNA Fragments from Agarose and Acrylamide Gels. Anal. Biochem. 112:295-298.

16. Driesel, E.J.. Crouse, E.J.K.. Gordon, K.. Bohnert, H.J. and Herrmann, R.G. (1979). Fractionation and Identification of Spinach Chloroplast Transfer RNAs and Mapping of their Genes on the Restriction Map of Chloroplast DNA. Gene 24:285-306.

17. Driesel, A.J., Speirs, J. and Bohnert, H.J. (1980). Spinach Chloroplast mRNA for a 32000 Dalton Polypeptide. Size and Localization on the Physical Map of the Chloroplast DNA. Biochim. Biophys. Acta 610:297-310.

18. Dyer. T.A. The Chloroplast Genome:Its Nature and Role in Development. In Topics in Photosynthesis vol. 5 Chloroplast Biogenesis. Baker, N.R. and Barber, J.. eds. Elsevier, Amsterdam, 1984.

19. E11is. J. (1982). Promiscuous DNA--Chloroplast Genes Inside Plant Mitochondria. Nature 299:185-186.

20. Ellis. J. (1983). Mobile Genes of Chloroplasts and the Promiscuity of DNA. Nature 304:308-309. 
11. Cohen, B.N., Coleman, T.A., Schmitt, J.J. and Weissbach, H. (1984). In vitrro Expression and Characterization Start Site of the psbA Gene Product ( $Q B$ Protein) from Higher Plants. Nuc. Acids Res. $12(15): 6221-6230$.

12. Courtice,G.R.M., Bowman, C.M. Dyer, T.A. and Gray, J.C. (1985). Localisation of Genes for Components of Photosystem II in Chloroplast DNA from Pea and wheat. Curr. Genet. 10:329-333.

13. Crouse, E.J., Bohnert, H.J. and Schmitt, J.M. Chloroplast RNA Synthesis. In Chloro이을 Biogenesis, El1is, R.J., ed. Cambridge University Press, Cambridge, 1984 .

14. Dorne, A.M., Heizman, D., Alt, J. and Mache, R. (1985). Spinach Chloroplast Genes Coding for Three Ribosomal Proteins. Mol. Gen. Genet. 198:521-524.

15. Dretzen, G. Bellard, M., Sassone-Corsi, P. and Chambon, P. (1981). A Reliable Method for the Recoverey of DNA Fragments from Agarose and Acrylamide Gels. Anal. Biochem. 112:295-298.

16. Driese1. E.J., Crouse, E.J.K., Gordon, K., Bohnert, H.J. and Herrmann, R.G. (1979). Fractionation and Identification of Spinach Chloroplast Transfer RNAs and Mapping of their Genes on the Restriction Map of Ch1oroplast DNA. Gene 24:285-306.

17. Driese1, A.J., Speirs, J. and Bohnert, H.J. (1980). Spinach Chloroplast mRNA for a 32000 Dalton Polypeptide. Size and Localization on the Physical Map of the Chloroplast DNA. Biochim. Biophys. Acta 610:297-310.

18. Dyer, T.A., The Chloroplast Genome:Its Nature and Role in Development. In Topics in Photosynthesis vo으. 5

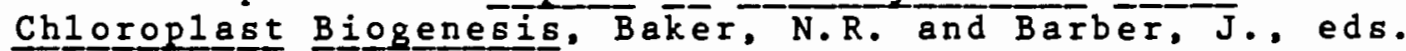
Elsevier, Amsterdam, 1984.

19. El1is, J. (1982). Promiscuous DNA--Ch1oroplast Genes Inside P1ant Mitochondria. Nature 299:185-186.

20. Ellis, J. (1983). Mobile Genes of Chloroplasts and the Promiscuity of DNA. Nature 304:308-309. 
21. Fluhr, R., Fromm, H. and Edelman, M. (1983). Clone Bank of Nicotiana tabacum Chloroplast DNA: mapping of the alpha, beta and epsilon subunits of the ATPase coupling factor, the large subunit of ribulosebisphosphate carboxylase, and the 32-kDal membrane protein. Gene $25: 271-280$.

22. Franke1, R., Scowcroft, W.R, and Whitfield, P.R. (1979). Chloroplast DNA Variation in Isonuclear Male-Sterile Lines of Nicotiana. Mol. Gen. Genet. 169:129-135.

23. Gray, J.C., Phillips, A.L. and Smith, A.G., Protein Synthesis by Chloroplasts. In Chloroplast Biogenesis. Ellis, R.J., ed. Cambridge University Press, Cambridge, 1984 .

24. Groot, G.S.P., Chloroplast DNA of Higher Plants. In Chloroplast Biogenesis. Ellis, R. J., ed. Cambridge University press, Cambidge, 1984.

25. Gruissem, W. Greenberg, B.M., Zurawski, G., Prescott, D.M. and Hallick. R.B. (1983). Biosynthesis of Chloroplast Transfer RNA in a Spinach Chloroplast Transcription System. Ce11 35:815-828.

26. Gruissem, W. Elsner-Menze1, C., Latshaw, S. Narita, J.0., Schaffer, M.A. and Zurawski, G. (1986). A Subpopulation of Spinach Chloroplast tRNA Genes does not Require Upstream Promoter Elements for Transcription. Nuc. Acid Res. 14(19):7541-7556.

27. Hachtel, W. (1982). Biosynthesis and Assembly of Thylakoid Membrane Proteins in Isolated Chloroplasts from Vicia faba L: The P700-Chhlorophyll a-Protein. $Z$. Pflanzeaphysiol. 107:383-394.

28. Hachtel. W. (1983). Biosynthesis and Membrane Insertion of a Chlorophylla/b-binding Protein by Isolated Vicia fabs L. Chloroplasts. Z. Pflanzenphysiol. 108:381-390.

29. Hanley-Bowdoin. L., Orozco, E.M. and Chua, N-H. (1985). In Vitro Synthesis and Processing of a Maize Chloroplast Transcript Encoded by the Ribulose 1.5 Bisphosphate Carboxylase Large Subunit Gene. Mol. and Cell. Biol. $5(10): 2733-2745$.

30. de Heiji, H.T., Lustig, H. Moeskops, D. M., Bovenberg, W.A. and Bisanz, C. (1983). Chloroplast DNAs of Spinacia. Petunia Spirodela Have a Similar Gene Organization. Curr. Genet. $7: 1-6$. 
31. de Heiji, H.T., Jochemsen, A-G., Willemsen, P.T.J. and Groot, G.S.P. (1984). Protein Synthesis During Ch1oroplast Development in Spirodela oligoriza. Eur. J. Biochem. 138:161-168.

32. Heinemeyer, W. A1t, J. and Herrmann, R.G. (1984). Nucleotide Sequence of the Clustered Genes for Apocytchrome b6 and Subunit 4 of the Cytochrome b/f Complex in the Spinach P1astid Chromosome. Curr. Genet. $8: 543-549$.

33. Hennig, J. and Herrmann, R.G. (1986). Chloroplast ATP Synthase of Spinach Contains Nine Nonidentical Subunit species. Six of which are Encoded by Plastid Chromosomes in Two Operons in a Phylogenetically Conserved

Arrangement. Mo1. Gen. Genet. 203:117-128.

34. Herrmann, R.G. Bohnert, H-J., Kowallik, K.V. and Schmitt. J.M. (1974). Size, Conformation and Purity of Chloroplast DNA of Some Higher Plants. Biochim. Biophys. Acta $378: 305-317$.

35. Herrmann, R.G.. Whitfield, P.R. and Bottomley, W. (1980). Construction of a Sall/Pst Restriction Map of Spinach Chloroplast DNA Using Low Gelling Temperature Agarose Elecrophoresis. Gene 8:179-191.

36. Herrmann. R.G., A1t, J., Schiller, B., Widger, W. R. and Cramer, W.A. (1984). Nucleotide sequence of the Gene for Apocytochrome b-559 on the Spinach Plastid Chromosome: Implications for the Structure of the Membrane Protein. FEBS Lett. 176(1):239-244.

37. Herrmann, R.G., Seyer, P., Schedel, R., Gordon, K., Bisanz, C., Winter, P., Hildebrandt, J.W.. Wlaschek, M., A1t, J., Driese1. A.J. and Sears, B.B.. The P1astid Chromosomes of Several Dicotyledons. In Biological Chemistry of Organelle Formation, Bucher, T. Sebald, W. and Weiss, H., eds. Springer-Verlag. Berlin, 1980.

38. Highfield, P.E. and E11is R.J. (1978). Synthesis and Transport of the Small Subunit of Chloroplast Ribulose Bisphosphate Carboxylase. Nature 271:420-424.

39. Holschuh, K. Bottomley, W. and Whitfield, P.R. (1984). Structure of the Spinach Chloroplast Genes for the D2 and $44 \mathrm{kd}$ Reaction-Centre Proteins of Pbotosystem II and for tRNASer (UGA). Nuc. Acids Res. $12(23): 8819-8834$. 
40. Kirsch, W.. Seyer, P. and Herrmann, R.G. (1986). Nucleotide sequence of the Clustered Genes for Two P700 Chlorophyll a Apoproteins of the Photosystem I Reaction Center and the Ribosomal Protein 514 of the spinach Plastid Chromosome. Curr. Genet. 10:843-855.

41. Kolodner, R. and Tewari, K.K. (1972). Molecular size and Conformation of Chloroplast Deoxyribonucleic Acid from Pea Leaves. J. Biol. Chem. 29:6355-6364.

42. Kolodner, R. and Tewari. K.K. (1975). The Molecular Size and Conformation of the Chloroplast DNA from Higher Plants. Biochim. Biophys. Acta 402:372-390.

43. Kolodner, R. and Tewari, K.K. (1975). Ch1oroplast DNA from Higher Plants Replicates by Both the Cairns and the Rolling Circle Mechanism. Nature 256:708-711.

44. Lebacq. P. and Vedel. F. (1981). SalI Restriction Enzyme Analysis of Chloroplast and Mitochondrial DNAs in the Genus Brassica. P1ant Sci. Let. 23:1-9.

45. Lerbs, S. and Mache, R. (1985). Immunological Comparison of the Polypeptides of DNA-dependent RNA Polymerase of Spinach Chloroplasts and E. Coli. Biol. Chem. H-S. $366: 819$.

46. Lyttleton. J.W. (1962). Isolation of Ribosomes from Spinach Chloroplasts. Exp. Ce11 Res. 26:312-317.

47. Maniatis, T., Fritsch, E.F. and Sambrook, J. Molecular Cloning A Laboratory Manual. Cold Spring Harbor Laboratory. Cold Spring Harbor, 1982 .

48. Margulis, L. Symbiosis In Cell Evolution. Walt Freeman and Co.. San Francisco. 1981 .

49. Morris, J. and Herrmnn, R.G. (1984). Nucleotide Sequence of the Gene for the P680 Chlorophy11 a Apoprotein of the Photosystem II Reaction Center for Spinach. Nuc. Acids Res. $12(6): 2837-2850$.

50. Palmer. J.D.and Thompson. W.F. (1981). C1one Banks of the Mung Bean. Pea And Spinach Chloroplast Genomes. Gene $15: 21-26$.

51. Palmer, J.D.. Singh, G.P. and Pillay D.T.N. (1983). Structure and Sequence Evolution of Three Legume Chloroplast DNAs. Mol. Gen.Genet. 190:13-19. 
52. Palmer, J.D. and Stein, D.B. (1986). Conservation of Chloroplast Genome structure among Vascular Plants. Curr. Genet. 10:823-833.

53. Palmer, J.D. (1985). Comparative Organization of Chloroplast Genomes. Ann. Rev. Genet. 19:325-354.

54. Palmer, J.D. (1986). Isolation and Structural Analysis of Chloroplast DNA. Methods in Enzymology 118:167-185.

55. Ris, R, and Plaut, C. (1962). U1trastructure of DNAContaining Areas of the Chloroplast of Chlamydomonas. J. Ce11 Biol. 13:383-391.

56. Scott, N.S. and Possingham. J.V. (1983). Changes in Chloroplast DNA Levels During Growth of Spinach Leaves. J. Exp. Bot. 34:1756-1767.

57. Seyer, P., Kowallik, K.V. and Herrmann, R.G. (1981). A Physical Map of Nicotiana tabacum Plastid DNA Including the Location of Structural Genes for Ribosomal RNAs and the Large Subunit of Ribulose Bisphosphate Carboxylase/ Oxygenase. Curr. Genet. 3:189-204.

58. Shinozaki, K., Sun, C-R. and Sugiura, M. (1984). Gene Organization of Chloroplast DNA from the Broad Bean Vicia faba. Mo1. Gen. Genet. 197:363-367.

59. Sijben-Muller, G., Hallick, R.B., A1t, J., Westoff, P. and Herrmann, R.G. (1986). Spinach Plastid Genes coding for Initiation Factor IF-1, Ribosomal Protein S11 and RNA Polymerase -subunit. Nuc. Acids Res. $14(2): 1029-1044$.

60. Spielmann, A., Ortiz, W.. and Stutz, E. (1983). The Soybean Chloroplast Genome: Construction of a Circular Restriction Site Map and Location of DNA Regions Encoding the Genes for rRNAs, the Large Subunit of the Ribulose-1.5-Bisphosphate Carboxylase and the $32 \mathrm{KD}$ Protein of the Photosystem II Reaction Center. Mol. Gen. Genet. 190:5-12.

61. Stern, D.B. and Lonsdale, D.M. (1982). Mitochondrial and Chloroplast Genomes of Maize Have a 12-kilobase DNA Sequence in Common. Nature 299:698-702.

62. Timmis, J.N. and Scott, N.S. (1983). Sequence Homology Between Spinach Nuclear and Chloroplast Genomes. Nature $305: 65-67$. 
63. Tittgen, J., Hermans, J., Steppuhn, J., Jansen, T., Jansson, C.. Andersson, B.. Nechushtai, R., Nelson, N. and Herrmann. R.G. (1986). Isolation of cDNA Clones for Fourteen Nuclear-Encoded Thylakoid Proteins. Mol. Gen. Genet. 204: 258-265.

64. Vieira, J, and Messing. J. (1982). The puC Plasmids, an M13mp7-Derived System for Insertion Mutagenesis and Sequencing with Universal Primers. Gene 19:259-268.

65. Watson. J.C., Palmer, J.D. and Thompson, W.F. (1983). Chloroplast Genes for the Translational Apparatus. Carnegie Inst. Yearb. 82:24-26.

66. Westoff, P., Nelson, N., Bunemann, H, and Herrmann, R.G. (1981). Localization of Genes for Coupling Factor Subunits on the Spinach Plastid Chromosome. Curr. Genet. $4: 109-120$.

67. Westhoff, P., A1t, J. and Herrmann, R.G. (1983). Localization of the Genes for the Two Chlorophyll a-Conjugated Polypeptides (mo1. wt. 51 and $44 \mathrm{kd}$ ) of the Photosystem II Reaction Center on the Spinach Plastid Chromosome. EMBO J. 2(12):2229-2237.

68. Westhoff, P.. A1t, J., Nelson, N., Bottomley, W.. Bunemann, H. and Herrmann, R.G. (1983). Genes and Transcripts for the P700 Chlorophyll a Apoprotein and Subunit 2 of the Photosystem I Reaction Center Complex from Spinach Thylakoid Membranes. Plant Mol. Bio. $2: 95-107$.

69. Westhoff, P.. Alt, J. and Herrmann. R.G. (1985). Genes and Transcripts for the ATP Synthase CFo Subunits I and II from Spinach Thylakoid Membranes. Mol. Gen. Genet. $199: 200-209$.

70. Westhoff, P., Alt, J., Widger, W.R., Cramer, W.A. and Herrmann, R.G. (1985). Localization of the Gene for Apocytochrome b-559 on the Plastid Chromosome of Spinach. P1ant. Mo1. Bio. 4:103-110.

71. Whitfield, P.R. and Bottomley. W. (1983). Chloroplast DNA. Ann. Rev. PIant Physiol. 34:280-310.

72. Zech, M., Hart1ey, M.R. and Bohnert, H.J. (1981). Binding Sites of E. coli DNA-Dependent RNA Polymerase on Spinach Chloroplast DNA. Curr. Genet. 4:37-46. 
73. Zurawski, G., Perrot, B.. Bottomley, W. and Whitfield P.R. (1981). The Structure of the Gene for the Large Subunit of Ribulose 1,5-Bisphosphate Carboxylase from Spinach Chloroplast DNA. Nuc. Acids Res. $9(14): 3251-3270$.

74. Zurawski, G., Bohnert, H.J., Whitfield, P.R. and Bottomley, W. (1982). Nucleotide Sequence of the Gene for the Mr 32,000 Thylakoid Membrane Protein from Spinacia oleracea and Nicotiana debneyi Predicts a Totaliy Conserved Primary Transiation Product of Mr 38,950 . PNAS 79:7699-7703.

75. Zurawski, G.. Bottomley and Whitfield, P.R. (1982). Structures of the Genes for the and subunits of Spinach Chloroplast ATPase Indicate a Dicstronic mRNA and an Overlapping Translation Stop/Start Signal. PNAS $79: 6260-6264$.

76. Zurawski, G., Bottomley, W. and Whitfield, P.R. (1984). Junctions of the Large Single Copy Region and the Inverted Repeats in Spinacia oleracea and Nicotiana debneyi Chloroplast DNA: Sequence of the Genes for tRNAHis and the Ribosomal Proteing S19 and L 2. Nuc. Acids Res. 12(16):6547-6558. 